PontIFícIA UNIVERSIDADE CATÓLICA DO RIO DE JANEIRO

\title{
O Indivíduo no Contexto da Mudança Organizacional
}

\author{
Kamila Umbelino Paiva
}

Trabalho de Conclusão de Curso

Centro de ciências socials - CCS

DePARTAMENTO de AdMINISTRAÇÃo

Curso de Graduação em Administração 


\title{
Kamila Umbelino Paiva
}

\section{O Indivíduo no Contexto da Mudança Organizacional}

\author{
Trabalho de Conclusão de Curso
}

Trabalho de Conclusão de Curso, apresentado ao programa de graduação em Administração da PUC-Rio como requisito parcial para a obtenção do titulo de graduação em Administração.

Orientadora: Lygia Magacho Co-Orientadora: Andrea Cherman 


\section{Agradecimentos}

Agradeço a Deus pela vida e pela fé.

Agradeço aos meus pais, Carlos e Helena, por todas as condições que tive de realizar tudo o que realizei até agora.

Agradeço à minha irmã, Vitória, por acreditar posso tudo.

Agradeço ao meu marido, Fellipe, por me incentivar e me fazer melhor a cada dia.

Agradeço às professoras Andrea Cherman e Lygia Magacho por seu tempo e sua atenção dada a este trabalho e por me aceitarem como orientanda.

Agradeço a todos os entrevistados que se dispuseram a contar suas história e contribuir com os resultados deste trabalho e também às pessoas que me apresentaram a esses entrevistados.

Agradeço aos meus gestores por serem compreensivos neste momento de construção deste trabalho.

Agradeço a todos que de alguma forma contribuiram para a existência deste trabalho final de curso - vocês sabem quem vocês são! 


\title{
Resumo
}

Paiva, Kamila. Magacho, Lygia. Cherman, Andrea. O Indivíduo no Contexto da Mudança Organizacional. Rio de Janeiro, 2016. 67p. Relatório Final de Estágio Supervisionado II - Departamento de Administração. Pontifícia Universidade Católica do Rio de Janeiro.

A mudança é simplesmente a transição de uma situação para outra diferente (CHIAVENATO, 2004). Diante disso, a questão que se pretende compreender com o estudo é a seguinte: Como os indivíduos lidam com a mudança organizacional, diante da maneira como ela é implementada? E o mundo atual, dinâmico e mutável, exige das organizações uma grande capacidade de adaptação à mudança como condição básica de sobrevivência. Por conta dessa necessidade de adaptação, muito se tem discutido sobre métodos de gestão da mudança organizacional. Este trabalho identificou que a maneira como a mudança é conduzida impacta diretamente na percepção dos colaboradores impactados.

\author{
Palavras-chave \\ Mudança, organizacional, percepções, reações, sentimentos,
}

\begin{abstract}
Paiva, Kamila. Magacho, Lygia. Cherman, Andrea. O Indivíduo no Contexto da Mudança Organizacional. Rio de Janeiro, 2016. 74p. Relatório Final de Estágio Supervisionado II - Departamento de Administração. Pontifícia Universidade Católica do Rio de Janeiro.
\end{abstract}

The change is simply the transition from one situation to another different (CHIAVENATO, 2004). Therefore, the question that is to be understood in this study is: How do individuals deal with organizational change, given the way it is implemented? The current world, dynamic and changeable, demands of organizations a great capacity to adapt to change as a basic condition for survival. Because of this need to adapt, much has been discussed about organizational change management methods. This work identified that the way the change is conducted directly impacts the perception of the affected employees.

Key-words

Change, organization, perception, reaction, feelings 


\section{Sumário}

1 O tema e o problema de estudo 1

1.1. Introdução ao tema e ao problema do estudo 1

1.2. Objetivo do estudo 2

1.3. Objetivos intermediários do estudo 3

1.4. Delimitação e foco do estudo 3

1.5. Justificativa e relevância do estudo 3

2 Revisão de literatura 5

2.1. Mudança Organizacional 5

2.1.1. Classificações e Tipos da Mudança Organizacional 7

2.1.2. Modelos de Implantação da Mudança Organizacional 8

2.1.2.1. As três fases da mudança segundo Lewin 8

2.1.2.2. Teoria do Desenvolvimento Organizacional 9

2.1.2.3. O Processo de Mudança em Oito Etapas de Kotter 10

2.2. Atores da Mudança Organizacional 13

2.3. Reações à Mudança Organizacional 13

$\begin{array}{ll}\text { 2.3.1. Resistência } & 14\end{array}$

$\begin{array}{lr}\text { 2.3.2. Resiliência } & 19\end{array}$

3 Métodos e procedimentos de coleta e de análise de dados do estudo 20

3.1. Tipo de pesquisa 20

3.2. Sujeitos da amostra 20

3.3. Coleta de dados $\quad 21$

3.4. Tratamento e análise de dados 22

3.5. Limitação do Método 23

4 Apresentação e Análise dos Resultados 24

4.1. Descrição do perfil dos entrevistados 24

4.2. Descrição e análises dos resultados 27

4.2.1. Classificação e tipo de mudança organizacional 27 
4.2.2. Estruturação da mudança e marcos do processo

4.2.3. Comunicação da mudança

4.2.4. Participação e responsabilidades

4.2.5. Abertura com os líderes 51

4.2.6. Percepções, sentimento e reações

5. Conclusões

6. Referências Bibliográficas

Apêndice

\section{Lista de Tabelas, Figuras e Gráficos}

Tabela 1

Tabela 2

Tabela 3

Tabela 4

Tabela 5

Tabela 6

Figura 1

Gráfico 1

Gráfico 2

Gráfico 3 


\section{0 tema e o problema de estudo}

Em tempos onde a mudança é uma constante, torna-se necessário um estudo sobre como se dá sua implantação em organizações e como os indivíduos tratam esse processo, sendo eles os que vão fazer ou não a mudança acontecer.

\subsection{Introdução ao tema e ao problema do estudo}

O mundo está cada vez mais acelerado: são novas tecnologias lançadas todos os dias, informações que levam apenas minutos para serem divulgadas, a busca por produtividade, a pressão por ter um melhor estilo de vida, e todas as incontáveis e constantes transformações que o planeta vem enfrentando em todos os aspectos de sua existência.

Segundo Robbins (2004), há certas forças que impulsionam para a mudança, como: a tecnologia que muda o trabalho e as organizações como um todo, os choques econômicos que não aconteciam de maneira tão inesperada como atualmente, a competição cada vez mais acirrada entre empresas, já que seus concorrentes podem estar na mesma rua ou do outro lado do mundo, entre outras questões.

Mas quando essas mudanças começaram a chamar a atenção das organizações, dos pesquisadores e dos indivíduos? Sabe-se que a humanidade vive em um constante processo evolucionário desde o aparecimento da vida e assim será para sempre. Então o que há de novo nesse último século? Para Conner (1995), é a magnitude que elas têm adquirido. Entende-se como magnitude a quantidade de transformações aliada à velocidade de suas ocorrências e o tempo de assimilação delas, somada à maior complexidade que essas mudanças possuem.

Diante desse cenário, onde a mudança é uma constante, as organizações precisam estar dispostas a sofrer adaptações para se manterem vivas e competitivas. Mudança organizacional para Palmer e Dunford (1996) é uma observação empírica na diferença da forma, da qualidade ou do estado de uma entidade da organização ao longo do tempo. Sendo entidade da 
organização definida como o trabalho de um indivíduo, um trabalho em grupo, a estratégia da empresa, um produto ou a organização como um todo.

Muito tem se discutido sobre gestão da mudança nas organizações e existem vários modelos para a sua implementação. Para Silva e Vergara (2003), no entanto, nos últimos anos tem se desenvolvido muitos estudos voltados para as pessoas no ambiente de mudança, depois de se observar várias tentativas fracassadas de gerir a mudança. Segundo os mesmos autores, as maiores dificuldades dizem respeito à comunicação dos objetivos da organização e à compreensão dos mesmos pelas pessoas, o que torna difícil a sua assimilação e consequentemente, a adoção de mudanças.

Os autores também criticam a maneira simplista como a questão da resistência dos indivíduos à mudança é estudada e defendem que as pessoas necessitam que a sua existência e atuação nas organizações faça algum sentido e que elas devem estar conscientes dos seus papéis de construtoras ativas da realidade que as cercam, pois ao contrário disso, os indivíduos são vistos como alguém que está ali para cumprir obrigações e exercer certos direitos. Dentre muitas outras, essa compreensão de papéis pode ser uma das raízes de onde surgem as principais reações positivas ou negativas quanto à mudança organizacional.

Silva (2001) ressalta que a mudança organizacional não pode ser entendida simplesmente como uma mudança de estratégia, processos ou estrutura, por exemplo, seguindo uma tradição funcionalista. Mas sim, como uma mudança de relações: do indivíduo com a organização, com seus pares, com a sociedade e, até mesmo, do indivíduo consigo mesmo.

Diante disto, pretende-se compreender a seguinte questão: como os indivíduos lidam com a mudança organizacional dada a maneira que ela é implementada?

\subsection{Objetivo do estudo}

Este estudo tem por objetivo principal analisar como os indivíduos lidam com a mudança organizacional, diante da maneira como ela é implementada. 


\subsection{Objetivos intermediários do estudo}

Para se atingir o objetivo final proposto, esse estudo prevê, como objetivos intermediários a serem alcançados:

- Identificar como os indivíduos lidam, em algum momento de suas vidas, com a mudança organizacional;

- Identificar os modos pelos quais as mudanças foram implementadas.

- Entender a relação entre as práticas de implementação de mudança da empresa e os consequentes comportamentos, positivos ou negativos, dos indivíduos.

\subsection{Delimitação e foco do estudo}

Serão pesquisadas pessoas que vivenciaram um processo de mudança organizacional em algum momento de suas vidas. Os dados serão do ano corrente (2016) e os entrevistados serão pessoas com no mínimo dez anos de atuação no mercado, preferencialmente, no Rio de Janeiro.

Esse estudo não tem por objetivo fazer medições de nenhum caráter, como: de satisfação no trabalho em meio à mudança, de objetivos atingidos pelo processo de mudança, de resultados financeiros, de clima organizacional, entre outros.

O foco será analisar a vivência dos indivíduos e seus comportamentos resultantes, no contexto da mudança organizacional, mediante as medidas adotadas pela empresa, quanto, por exemplo: ao grau de controle dado pela organização percebido pelos indivíduos, a maneira como a mudança foi comunicada, ao grau de envolvimento que foi proporcionado aos indivíduos, entre outros.

\subsection{Justificativa e relevância do estudo}

A escolha do tema se deu por parte de curiosidade sobre o tema da autora do trabalho. O tema de mudança organizacional é muito amplo e há diversos estudos sobre ele, porém há críticas de certos autores com respeito à abordagem que adquire quando foca mais no processo em si e esquece de pesquisar sobre o que de fato ela representa para o indivíduo que vivencia a 
mudança, como ele é afetado, e quais comportamentos manisfestam em decorrência dessas formas de implantação da mudança.

O estudo é relevante para a academia, pois terá mais fontes de conhecimento e discussão sobre o tema. Para as empresas que passam por processos constantes de mudanças e desejam entender mais sobre esse fenômeno, para gerentes de pessoas que querem entender mais sobre as reações de seus funcionários em dadas situações, para profissionais inseridos no mercado de trabalho que desejam também mais conhecimento sobre o tema, a fim de estarem preparados para enfrentar processos de mudanças, para futuros ingressantes no mercado, que estarão mais cientes de suas posições ao adentrarem em tal. 


\section{Revisão de literatura}

Neste capítulo são apresentados e discutidos aspectos conceituais e estudos relacionados ao tema e estudo em investigação e que servirão de base para a análise realizada.

Esta seção está dividida em três partes e abordam, respectivamente, a questão da mudança organizacional e uma evolução de como foi e é compreendida até os dias de hoje, segundo três principais autores Lewin (1947), Conner (1995) e Kotter (1997). Depois foi abordada a questão do papel que os indivíduos exercem na organização em tempos de mudança na perspectiva de Conner (1995).

Por fim a última seção apresenta as reações mais comuns à mudança organizacional sob a perspectiva de Robbins (2004) e com comentários sobre os três autores anteriormente citados.

\subsection{Mudança Organizacional}

Chiavenato (2004) fala que mudança é simplesmente a transição de uma situação para outra diferente e que o mundo atual, dinâmico e mutável, exige das organizações uma grande capacidade de adaptação à mudança como condição básica de sobrevivência. Essas mudanças organizacionais acontecem, segundo Kotter (1997), para aperfeiçoar o desempenho gerencial de dada empresa e podem ser de diversos tipos, como: reestruturação, downsizing, reengenharia, programas de qualidade, fusões e aquisições, renovação cultural, redirecionamento estratégico, entre outros.

Para Palmer e Dunford (1996), mudança organizacional é a observação empírica de dada diferença na forma, no estado ou numa entidade organizacional ao longo do tempo. Os autores também definem como entidade organizacional desde o trabalho do indivíduo ou do grupo, a estratégia da organização, o produto, até a organização como um todo.

Segundo Conner (1995), sempre houve mudanças desde os primórdios do mundo. $\mathrm{O}$ que faz as mudanças que vem acontecendo na atualidade serem tão diferentes das demais ocorridas na história é a magnitude que elas vêm 
adquirindo no último século. Entende-se por magnitude as três dimensões seguintes: volume, que se refere à quantidade de mudanças que deve-se confrontar; momentum, que se refere ao tempo de implantação da mudança, somado ao tempo que acontecerá a próxima mudança necessária; e a complexidade que tem sido muito maior hoje do que no passado.

Silva (2001) apresenta pontos convergentes, onde as definições de diferentes autores sobre mudança organizacional se encontram, tais como: a existência de um estado original na organização, que por algum motivo, tem suas características modificadas no tempo; a existência de um momento intermediário de transição ou evolução; a existência de um novo estado que pode não ser o estado final, mas que apresenta características diferentes das existentes no estado original.

Segundo Robbins (2004), há seis principais forças que impulsionam para a mudança, que são: (i) a natureza da força de trabalho, que se refere a um ambiente multicultural, onde as empresas têm que a cada vez mais, buscar novas formar de atrair, reter e desenvolver talentos; (ii) a tecnologia que muda o trabalho e as organizações como um todo; (iii) os choques econômicos que não aconteciam de maneira tão inesperada como atualmente; (iv) a competição cada vez mais acirrada entre empresas, já que seus concorrentes podem estar na mesma rua ou do outro lado do mundo; (v) as tendências sociais que mudaram com o nascimento de novas gerações mais predispostas à tecnologia; e (vi) a política internacional, que no mundo globalizado, por causa do elo entre os mercados globais, torna-se um importante ponto a ser observado.

Conner (1995) acredita que há sete fatores que tem contribuído para o aumento da magnitude das mudanças, e são eles: (i) maior rapidez na comunicação e na aquisição de conhecimento; (ii) população mundial em crescimento; (iii) interdependência e competição progressivas; (iv) recursos limitados; (v) ideologias políticas e religiosas variadas; (vi) transições constantes de poder; e (vii) esgotamento ecológico. Para ele cada um desses fatores isoladamente já possui grande complexidade e exige que diversas mudanças sejam feitas, então quando eles interagem entre si, que é o que acontece no mundo real, as questões ficam ainda mais complexas e geram ainda mais necessidade de mudanças.

Nota-se que as ideias dos dois autores supracitados convergem na ideia de formação de um ambiente multicultural, que dentre outros, é comporto por ideologias políticas e religiosas variadas, na questão da tecnologia que pode ser relacionada à maior rapidez na comunicação e aquisição de novos 
conhecimentos e a na questão da competição mais agressiva e acirrada, observada pelos dois autores.

O conceito de mudança organizacional é genérico e abrangente, permitindo que uma variedade de eventos e processos sejam definidas por tal conceito. Para Silva (2001), os focos da abordagem variam de acordo com a função da origem, do processo gerador, do contexto, da finalidade da mudança, entre outros. Por isso é importante deixar claro qual é o conceito de mudança assumido, para tanto, falaremos a seguir das classificações que as mudanças organizacionais podem assumir.

\subsubsection{Classificações e Tipos da Mudança Organizacional}

Sobre os tipos de mudança Tersine, Harvey e Buckley (1997, apud Silva, 2001) propõe um mapa mental da figura a seguir que ajuda a identificar de que tipo de mudança se trata ao estabelecer os parâmetros básicos de dada mudança. O eixo horizontal se refere à intensidade do fato e deve ser medida em normal, contínua e severa. Já o eixo vertical diz respeito ao caráter da mudança, ou seja, se é mais fortemente baseada em alterações de natureza técnica ou econômica, ou em alterações de natureza humana e social.

Figura 1: Mapa mental sobre mudanças organizacionais Fonte: Tersine, Harvey e Buckley (1997, apud Silva, 2001, p. 26)

\begin{tabular}{|c|c|}
\hline \multicolumn{2}{|c|}{ Técnica / Econômica } \\
\hline $\begin{array}{l}\text { - Introdução de novos } \\
\text { produtos } \\
\text { - abertura de novas } \\
\text { instalações } \\
\text { - flutuação no valor das ações } \\
\text { - abertura de novo mercado } \\
\text { - entrada de novo competidor }\end{array}$ & $\begin{array}{l}\text { - Introdução de nova tecnologia } \\
\text { revolucionária por competidor } \\
\text { - depressão econômica } \\
\text { - takeover hostil } \\
\text { - mudança significativa de } \\
\text { regulamentação }\end{array}$ \\
\hline \begin{tabular}{|l} 
Mudança normal \\
• Aquisição de outra \\
organização \\
- contratação de novas \\
pessoas \\
• realocação de pessoal \\
- reorganização
\end{tabular} & $\begin{array}{l}\text { - Downsizing radical } \\
\text { - reengenharia } \\
\text { - ações legais significativas contra } \\
\text { a organização } \\
\text { - fechamento de instalação } \\
\text { - entrada em mercado internacional } \\
\text { - estabelecimento de uma } \\
\text { organização virtual }\end{array}$ \\
\hline Huma & Social \\
\hline
\end{tabular}


Quanto à classificação de mudanças Ford e Ford (1995), as classifica como intencionais ou não intencionais. Mudanças intencionais acontecem quando um agente de mudança estabelece conscientemente e deliberadamente ações que mudarão a situação da empresa de um estado atual para um que se deseja alcançar. Já as mudanças não intencionais, como o nome propõe, são fruto de acidentes, efeitos secundários, ou consequências de ações que não eram deliberadas, nem conscientes da intenção de mudar, por exemplo.

\subsubsection{Modelos de Implantação da Mudança Organizacional}

A seguir serão abordados modelos de implantação de mudança organizacional de maneira cronológica, buscando entender em que contexto ela começa a ser pensada e as evoluções que ocorreram no conceito de mudanças e os que permanecem até os dias de hoje.

\subsubsection{As três fases da mudança segundo Lewin}

O primeiro autor a pensar em mudança organizacional foi o psicólogo social Kurt Lewin, em 1947, e seu modelo de mudança envolve três etapas:

- Descongelamento do padrão atual de comportamento, o status quo, onde práticas antigas são abandonadas para serem substituídas por novas ideias.

- Mudança, quando as novas práticas são aprendidas, ou seja, as pessoas têm seu comportamento mudado e passam a pensar e executar tarefas do novo modo estabelecido.

- Recongelamento que acontece quando as novas práticas são definitivamente absorvidas pelas pessoas e incorporadas a seu comportamento como rotina de seu trabalho. Isso através de sistemas de reforço e suporte.

Para Lewin (1947), a mudança sofre ação de duas forças que são opostas entre si: forças positivas ou impulsionadoras que agem no sentido da mudança, dando apoio e suporte à mesma; e forças negativas ou restritivas que trabalham em sentido contrário à mudança. Diante disso, faz-se necessária a análise de tais forças de modo a remover as forças restritivas e incentivar as forças impulsionadoras, para que a mudança seja enfim implantada, pois ela só ocorrerá quando as últimas forem maiores do que as primeiras (CHIAVENATO, 2004). 


\subsubsection{Teoria do Desenvolvimento Organizacional}

A teoria do Desenvolvimento Organizacional (DO) surgiu no início da década de 60 , não como uma teoria da administração, mas como um movimento de vários autores com ideias integradas sobre o homem, a organização e o ambiente, para fomentar o desenvolvimento das organizações, promover a mudança e a flexibilidade nas mesmas. Ela nasce nesta época como resposta às diversas transformações no ambiente interno e externo às organizações, e está relacionada a conceitos de mudança e capacidade adaptativa das pessoas a essas transformações (Chiavenato, 2004).

A ênfase do DO está na mudança planejada da cultura organizacional, através de transformações que ocorrerão nas pessoas e nas suas relações com o trabalho. Seus pressupostos básicos são: (i) a existência de uma constante e rápida mutação do ambiente (ii) que gera uma necessidade contínua de adaptação; (iii) a interação entre individuo e organização; (iv) a necessidade de planejamento da mudança organizacional que se torna possível quando há (v) participação e comprometimento das equipes; (vi) a melhoria da eficiência organizacional e do bem estar organizacional; (vii) a variedade de modelos e estratégias que o DO possui, o possibilitando de ser aplicado em diferentes situações; (viii) o modelo é uma resposta às mudanças ambientais externas e internas.

Robbins (2004) diz que o agente de mudança é o responsável por ser o orientador do desenvolvimento organizacional, contudo há uma grande ênfase na colaboração de todos os funcionários. Esse agente de mudança deve considerar cinco intervenções para o sucesso do processo de mudança planejada, como propõe o DO:

(i) Treinamento e sensibilidade que se refere a um método de interação de grupo não estruturado, onde as pessoas tem um espaço livre e aberto, aonde conduzido por um orientador, discutem sobre seus processos interativos, a fim de adquirir uma maior consciência sobre seu comportamento e dos outros, com o objetivo de promover uma mudança comportamental, maior sensibilidade ao outro, aumento de tolerância com diferenças, entre outros;

(ii) Levantamento de feedback, pode ser usado para avaliar a percepção dos funcionários em relação a determinado assunto. É feito um questionário que é passado aos funcionários da empresa, 
ou de apenas uma equipe. As perguntas podem ser sugeridas pelos próprios funcionários também e com as respostas torna-se possível esclarecer problemas ou solucionar alguma questão que causava desconforto nas pessoas;

(iii) Consultoria de processos que é quando um consultor externo é contratado para auxiliar um gerente, por exemplo, a identificar quais processos necessitam de melhorias;

(iv) Construção de equipes que tem por objetivo promover a confiança e a abertura entre os membros das equipes, sentimentos que normalmente são abalados em processos de grandes transições; e por último,

(v) O desenvolvimento intergrupal que pretende promover a mudança de atitudes de certos grupos frente a outros com a eliminação dos estereótipos, por exemplo, que tem impactos negativos na interação de grupos.

Para Palmer, Dunford e Akin (2009), as técnicas do DO usadas para a mudança organizacional se desenvolveram ao longo do tempo e foram influenciadas por numerosas e diferentes trajetórias. Por isso não há uma teoria única e representativa que defina o campo de estudo do DO como um todo, pelo contrário, há uma variedade de diferentes perspectivas e diferentes estudiosos como Herzberg, Maslow, Lewin e outros.

Todas as intervenções mencionadas aqui se referem ao indivíduo ou ao grupo ao qual eles fazem parte, pois como dito anteriormente o DO tem o foco nas pessoas e nas suas relações com o trabalho e acredita que o crescimento organizacional advém, dentre outras coisas, do crescimento do ser humano.

\subsubsection{O Processo de Mudança em Oito Etapas de Kotter}

Nenhum processo de mudança é tarefa simples e ainda que seja identificada claramente a necessidade de fazê-la, serão encontrados muitos empecilhos, seja por uma cultura centrada nas necessidades internas, pela falta de trabalho em equipe, por atitudes arrogantes, ou pelo simples medo do desconhecido. Para lidar com essas barreiras, Kotter (1997) apresenta um modelo que tenta resumir em oito etapas o processo de execução da mudança de qualquer dimensão nas organizações, o chamado processo de mudança em oito etapas. 
Antes de chegar ao modelo, Kotter faz duas importantes ressalvas. A primeira quanto à ordem em que as etapas devem ser executadas no processo, que deve seguir a sequência apresenta por ele, apesar de algumas etapas acontecerem simultaneamente. $\mathrm{E}$, a segunda, quanto à necessidade de uma liderança de alta qualidade e não somente um excelente gerenciamento. Uma vez que, enquanto a última estabelece etapas detalhadas de um planejamento, organiza os melhores recursos para sua a execução e os controla para solucionar problemas, a primeira cria uma visão clara de longo prazo que é comunicada com palavras e com ações às pessoas que compram a ideia por terem sido inspiradas e motivadas pela liderança.

A primeira etapa é o estabelecimento do senso de urgência nos seus gerentes e funcionários, pois muitas vezes o positivismo excessivo ou uma cultura arrogante impede que a inércia do status quo seja vencida. Nessa fase permitir complacência excessiva é um grande erro e deve ser evitado e crises podem ser propositalmente criadas e estimuladas.

A segunda etapa trata da criação de uma coalização administrativa, que se refere à formação de uma equipe administrativa forte e coesa de pessoas, com objetivos comuns e compartilhados, trabalhando para o mesmo fim. Isso é importante, pois indivíduos sozinhos, independente de suas capacidades ou habilidades, são incapazes de vencer a inércia e gerar grandes transformações, principalmente em grandes organizações.

A terceira etapa consiste no desenvolvimento de uma visão, ou seja, um quadro do futuro que se deseja alcançar e que irá dirigir, alinhar e inspirar ações por parte de um grande número de pessoas (Kotter, 1997) e de uma estratégia que definirá como a visão será alcançada. É necessário que a visão seja clara e precisa para despertar a compreensão e o interesse das pessoas, para que elas se sintam seguras e encorajadas ao entenderem a razão pela qual devem lutar.

A quarta etapa é a comunicação da visão da mudança e está diretamente relacionada à anterior. Mudanças exigem sacrifícios e pessoas somente farão tais sacrifícios se conseguirem imaginar recompensas atraentes que eles trarão ou se realmente acreditarem que a mudança é de fato possível. Para isso acontecer, faz-se necessária uma comunicação franca e confiável por meio de palavras e ações, para o autor a última tem maior peso, pois palavras podem ser esquecidas, mas ações, dificilmente. "Nada mina mais a comunicação de uma visão de mudança do que um comportamento inconsistente..." (KOTTER,1997, p. 47). Além disso, a nova visão deve ser amplamente difundida aos funcionários 
ao ponto de eles serem capazes de olhar para suas tarefas diárias pela ótica desta visão.

$\mathrm{Na}$ quinta etapa, o autor explora como investir de empowerment os funcionários, isso faz com que o indivíduo sinta-se envolvido e parte do processo. Ele diz que funcionários que se dispõe a correr riscos devem ser recompensados.

A próxima etapa é a observância à realização de conquistas de curto prazo, pois por muitas vezes por se tratar de um processo demorado com resultados que se veem somente em anos, o não estabelecimento de metas de curto prazo e a falta de comemoração de seu cumprimento, pode desanimar e desmotivar as pessoas que não conseguem ver os resultados de seus esforços.

A sétima etapa é a consolidação de ganhos e produção de mais mudanças, que está diretamente relacionada a um erro muito grave que as organizações podem cometer: declarar vitória prematuramente. Se comemorar conquistas ao longo do processo de mudança é importante, afirmar que o processo foi um sucesso sem a certeza de que todas as mudanças foram profundamente assimiladas pode ser um erro terrível, uma vez que as estruturas ainda podem estar frágeis e sujeitas à regressão.

Diante dos resultados já alcançados e dos primeiros estágios bemsucedidos, as pessoas podem achar que já fizeram todo o trabalho e relaxarem, diminuindo o senso de urgência e muitas vezes destruindo tudo o que foi estabelecido, pois é neste momento que as forças de resistência à mudança podem se reerguer.

Por isso a importância da oitava etapa, estabelecimento de novos métodos na cultura. Essa etapa determina que a mudança foi verdadeiramente estabelecida apenas quando as novas práticas se enraízam nos valores e normas sociais da corporação, ou seja, quando se torna numa nova cultura da organização.

Esse modelo tem por base o modelo anteriormente citado de Kurt Lewin (1947), onde da primeira à quarta fase, se remete ao descongelar, da quinta à sétima à fase de mudança e a última, à fase de recongelamento. Modelos atuais desconsideram esta última fase e atualmente a mudança é uma constante, que não tem um fim, mas sim novas adaptações. 


\subsection{Atores da Mudança Organizacional}

Para Conner (1995), há quatro importantes papéis a serem desempenhados no processo de mudança, que são os seguintes: de patrocinador, de agente, de alvo e de defensor. O patrocinador é o indivíduo ou grupo que tem o poder de determinar quais mudanças acontecerão e é responsável pela criação de um ambiente propício ao estabelecimento das transformações. Os agentes são responsáveis por colocar os planos feitos pelos patrocinadores em prática, eles também têm a incumbência de diagnosticar os possíveis problemas e encontrar meios para lidar com eles, de modo que a mudança não seja interrompida. Alvo são as pessoas que sofrerão o processo de mudança e para que o processo tenha sucesso é importante que eles compreendam e se adaptem às novas regras. O último papel é o de defensor que são aquelas pessoas que identificam a necessidade de uma mudança, porém não têm o poder para sancioná-las.

Pessoas podem exercer diferentes papéis durante o processo da mudança, às vezes um gerente pode ser agente para o diretor ou presidente, mas ser visto como um patrocinador pelos seus funcionários. Em outros momentos aqueles que eram alvos podem se tornar agentes, a partir do momento que compreendem tão bem o processo, a ponto de poderem difundir as novas ideias para outros alvos.

O autor também diz que esses papéis não são facilmente identificados nos organogramas das organizações, ou seja, independe, em parte, do nível hierárquico. "Em parte", pois enquanto os patrocinadores têm o poder de sancionar mudanças, os defensores, não. Mesmo assim aqui fica reforçado o que mostrou Kotter (1997) quando fala da necessidade de uma equipe administrativa forte e coesa, que caminhem para os mesmos objetivos, pois o indivíduo sozinho, seja até mesmo um patrocinador depende de que outros comprem e difundam suas ideias.

\subsection{Reações à Mudança Organizacional}

Para falar das reações que os indivíduos manifestam frente a mudanças, Conner (1995), usa o termo "choques futuros", que foi primeiramente popularizado pelo observador social Alvin Toffer em 1965. Choques futuros são reações negativas que são geradas no indivíduo quando ele não é capaz de assimilar as transformações de dado processo, na mesma velocidade que elas 
estão acontecendo, "é o estresse e a desorientação que causamos nos indivíduos, ao sujeitá-los a muitas mudanças em pouco tempo" (Toffer, 1970, p.8).

Para Conner (1995), quando as pessoas são submetidas a esse estresse, elas começam a desenvolver alguns comportamentos disfuncionais, desde os mais leves, como: comunicação deficiente e confiança reduzida, comportamento defensivo e acusatório, decisões mal tomadas; evoluindo para absenteísmo crônico, apatia e complacência, até chegar aos mais severos, como: destruição dissimulada da liderança organizacional, greve, sabotagem, depressão profunda e até mesmo o suicídio. Para evitar tal estresse causado pelas mudanças organizacionais, o autor sugere que os líderes gerenciem cuidadosamente 0 fluxo das mudanças, mas para isso acontecer é necessário que esses líderes, patrocinadores da mudança, tenham em si uma boa dose de resiliência.

É importante ressaltar, que as reações negativas não advêm necessariamente de mudanças negativas. A transformação pode ser muito positiva e gerar muitos benefícios para o indivíduo, mas mesmo assim o estresse pode ser gerado, a partir do momento em que o indivíduo não se vê capaz de absorver dadas mudanças. Sobre isso, o autor diz também que a mudança é classificada como positiva ou negativa mediante a percepção que cada pessoa tem sobre o evento e de acordo com o grau de controle que ela exerce sobre a situação. Quando a necessidade de controle é atendida o indivíduo se conforta, pois pode prever o que acontecerá, porém quando o contrário acontece, surge então o desconforto da incerteza.

\subsubsection{Resistência}

Resistência é um sentimento comum às organizações e aos indivíduos e as fontes de resistência organizacionais estão relacionadas à estrutura da mesma, à inércia do grupo, entre outros; já as fontes de resistência individuais, à sua percepção, personalidade ou necessidade. É importante ter em mente que ela não é sempre negativa, pois num contexto de normalidade ela garante certa estabilidade e previsibilidade do comportamento humano e em contextos de mudanças, esse sentimento pode produzir discussões e até promover ideias melhoradas para o processo, porém a resistência dificulta as adaptações e a evolução (ROBBINS, 2004). 
Segundo Robbins (2004), a resistência pode acontecer de diversas formas, seja ela explícita, como: boicotes de funcionários ou manifestações contrárias à liderança; e de maneira implícita, como: perda de lealdade à empresa, aumento de erros e absenteísmo ou falta de motivação. Autores como Conner (1995) e Kotter (1997), assim como outros pesquisadores do assunto, concordam que a forma mais difícil de lidar com a resistência é no segundo caso, quando ela é implícita. Para Conner (1995), os gerentes devem promover e estimular o diálogo sobre a resistência e até premiar os funcionários que dão sua opinião sincera a respeito do assunto.

Palmer, Dunford e Akin (2009) dizem que a resistência à mudança é tridimensional e envolve os componentes sentimental, comportamental e cognitivo. O componente sentimental diz respeito ao que o indivíduo sente em relação à mudança; o cognitivo fala sobre o que ele pensa a respeito da mudança; e o comportamental diz respeito ao que ele faz diante da mudança.

Para esses autores há algumas razões para as pessoas resistirem à mudança, das quais pode-se citar:

- O desconforto causado pela incerteza que acontece quando os indivíduos não sabem o que esperar, nem o que é esperado deles no processo de mudança;

- Efeitos negativos percebidos em seus interesses, pois as pessoas dão mais suporte à mudança onde elas identificam algum ganho para si, contudo quando a mudança é vista como uma ameaça a seus interesses, a tendência é que resistam à mesma.

- O apego a uma cultura organizacional já estabilizada, pois quando o indivíduo entra em dada organização, é esperado dele que se ajuste àquela organização, adotando comportamentos que são dele esperados, compartilhando os mesmos valores e costumes. Então, quanto maior é o grau de apego do indivíduo à cultura organizacional existente e o quanto ela está enraizada nele, há mais chance de resistência à mudança.

- Violação percebida do contrato psicológico, acontece quando o indivíduo percebe que seu empregador não está mais honrando com sua parte no acordo. O contrato psicológico possui três dimensões: a formal, o que foi firmado entre as partes a respeito de tarefas, hierarquias, normalmente é o que está no papel; a psicológica que está relacionada a expetativas de confiança, lealdade e reconhecimento; e a terceira dimensão, social, que está 
relacionada aos valores da organização. Quando a mudança proposta conflita com algum desses elementos, manifestações de resistência são mais esperadas.

- Há outros ainda como: falta de convicção de que a mudança é realmente necessária; crenças de que a mudança está sendo implementada de maneira errada; crença de que o momento não é apropriado para a mudança acontecer;

- Quando há um excesso de mudança por parte da organização, que acontece quando a organização está pressionando por várias iniciativas de mudança, percebida pelos indivíduos como não relacionadas ou até conflituosas entre si. Pode acontecer também quando um excesso de transformações leva os indivíduos a fadiga;

Kets de Vries e Balazs (1999, apud Silva, 2001) identificam:

"as principais fontes de resistências à mudança, que variam em função da situação dos indivíduos no processo, entre as quais destacam: a perda de segurança; o medo do desconhecido que causa ansiedade, resultando no desejo de retornar aos antigos padrões de comportamento; o sentimento de que não possuem suficiente competência e fibra para os novos aprendizados que a mudança implica; o medo de que as boas condições de trabalho ou a liberdade possam ser perdidas; o medo de que a mudança possa implicar a perda de responsabilidade e autoridade, com concomitantes implicações de status; o medo de perder direitos ou privilégios; o sentimento de que a mudança é uma punição ou represália a ações anteriormente realizadas; o sentimento de que a mudança é um ataque ao seu desempenho passado; a ameaça de perda de amigos, de contatos e alianças." (SILVA, 2001, p. 47)

Uma receita clássica para gerenciar a resistência à mudança é proposta por Kotter e Schlesinger (1979, apud Palmer, Dunford e Akin, 2008). Os autores propõem seis táticas que os agentes da mudança podem usar para superá-la, tais quais: (i) A educação e comunicação: quando os funcionários entendem a lógica da mudança, a resistência pode ser reduzida; (ii) Participação e envolvimento: quando as pessoas se tornam participativas na decisão é mais difícil que resistam às mesmas.

Essas duas primeiras táticas podem ser relacionadas à terceira etapa do processo de Kotter (1997), comunicando a visão, e ao que Conner (1995) fala a respeito da necessidade de controle que o indivíduo possui para sentir-se seguro. 
A tática seguinte é (iii) de facilitação e apoio: os agentes podem oferecer artifícios que capacitem ou preparem o funcionário para a mudança, como terapias, treinamentos ou mesmo um descanso remunerado; (iv) Negociação e acordo: como sugere o nome o agente pode negociar algo valioso, por certa abertura da resistência, normalmente usada no caso de pessoas poderosas na organização; (v) Manipulação e cooptação: a primeira refere-se a influências disfarçadas, à omissão de informações para tornar a mudança mais atraente, já a segunda é uma espécie de barganha com os líderes dos grupos de resistência, oferecendo-lhe papéis de importância nas decisões sobre a mudança. A última tática é (vi) a coerção explícita ou implícita: o uso de ameaças ou de força contra os resistentes.

Algumas dessas táticas possuem suas desvantagens: a (iii) e (iv), por exemplo, podem levar muito tempo para trazer resultados e custar muito caro, respectivamente. Já a (v) e (vi), podem afetar a confiança dos funcionários nas lideranças. Por muitas vezes vemos os autores aqui citados falarem da importância de construir uma relação de confiança entre os membros das equipes e nas lideranças, o que torna a utilização dessas últimas duas táticas até contraditória.

As duas primeiras táticas, no entanto, tendem a reforçar o sentimento de confiança e de participação dos membros da empresa na mudança, aumentando assim o grau de envolvimento com o processo e consequentemente diminuindo a insegurança quanto ao desconhecido.

A tabela a seguir resume o método que pretende gerenciar a resistência dos indivíduos à mudança e os relaciona com suas características, o contexto onde dever ser usado e os possíveis problemas que podem ser encontrados com a adoção de cada tática.

Tabela 1 - Métodos de Gerenciar a Mudança de Kotter e Schlesinger

\begin{tabular}{|l|l|l|l|}
\hline \multicolumn{1}{|c|}{ Táticas } & \multicolumn{1}{|c|}{ Características } & \multicolumn{1}{c|}{$\begin{array}{c}\text { Contexto } \\
\text { (Onde usar) }\end{array}$} & \multicolumn{1}{c|}{$\begin{array}{c}\text { Problemas } \\
\text { (Possíveis dificuldades) }\end{array}$} \\
\hline $\begin{array}{l}\text { Educação e } \\
\text { Comunicação }\end{array}$ & $\begin{array}{l}\text { Informa às pessoas as } \\
\text { razões da mudança; } \\
\text { fornece informações }\end{array}$ & $\begin{array}{l}\text { Onde a resistência é } \\
\text { causada pela falta de } \\
\text { informação ou má } \\
\text { qualidade de informação }\end{array}$ & $\begin{array}{l}\text { Pode consumir muito tempo, o } \\
\text { que em alguns casos de } \\
\text { mudança, pode ser um } \\
\text { problema bem significante. }\end{array}$ \\
\hline
\end{tabular}




\begin{tabular}{|c|c|c|c|}
\hline $\begin{array}{l}\text { Participação e } \\
\text { Envolvimento }\end{array}$ & $\begin{array}{l}\text { Envolve as pessoas no } \\
\text { processo de mudança } \\
\text { como participantes } \\
\text { ativos. }\end{array}$ & $\begin{array}{l}\text { Quando a resistência é } \\
\text { devido ao sentimento de } \\
\text { exclusão do processo. }\end{array}$ & $\begin{array}{l}\text { Pode tornar o processo } \\
\text { demorado e pode introduzir } \\
\text { elementos que comprometam } \\
\text { as decisões, reduzindo a } \\
\text { otimização da mudança. }\end{array}$ \\
\hline $\begin{array}{l}\text { Facilitação e } \\
\text { apoio }\end{array}$ & $\begin{array}{l}\text { Fornece recursos, tanto } \\
\text { técnicos como } \\
\text { emocionais. }\end{array}$ & $\begin{array}{l}\text { Quando a resistência } \\
\text { advém de ansiedades e } \\
\text { incertezas. }\end{array}$ & $\begin{array}{l}\text { Requer recursos financeiros, } \\
\text { tempo e apoio interpessoal } \\
\text { que os gerentes podem não } \\
\text { se sentirem capazes ou } \\
\text { preparados para oferecer. }\end{array}$ \\
\hline $\begin{array}{l}\text { Negociação e } \\
\text { acordo }\end{array}$ & $\begin{array}{l}\text { Oferece incentivos para } \\
\text { resistentes atuais ou } \\
\text { potenciais. }\end{array}$ & $\begin{array}{l}\text { Quando os resistentes } \\
\text { estão em posições fortes } \\
\text { para minar a mudança se } \\
\text { seus interesses não } \\
\text { forem atendidos. }\end{array}$ & $\begin{array}{l}\text { Pode enfraquecer os } \\
\text { elementos chaves da } \\
\text { mudança. }\end{array}$ \\
\hline $\begin{array}{l}\text { Manipulação e } \\
\text { cooptação }\end{array}$ & $\begin{array}{l}\text { Uso seletivo de } \\
\text { informações; "compra" o } \\
\text { apoio de certos } \\
\text { indivíduos, dando a eles } \\
\text { papéis chaves no } \\
\text { processo da mudança. }\end{array}$ & $\begin{array}{l}\text { Quando a participação, } \\
\text { facilitação ou a } \\
\text { negociação consomem } \\
\text { muito tempo ou } \\
\text { demandam muitos } \\
\text { recursos. }\end{array}$ & $\begin{array}{l}\text { Essa abordagem corre o risco } \\
\text { de criar revoltas se for visto } \\
\text { como antiético. }\end{array}$ \\
\hline $\begin{array}{l}\text { Coerção } \\
\text { explícita ou } \\
\text { implícita }\end{array}$ & $\begin{array}{l}\text { Ameaçar pessoas com } \\
\text { consequências } \\
\text { indesejáveis, como a } \\
\text { demissão por exemplo, } \\
\text { àqueles que resistirem. }\end{array}$ & $\begin{array}{l}\text { Quando a sobrevivência } \\
\text { da organização está em } \\
\text { risco, caso a mudança } \\
\text { não aconteça logo. }\end{array}$ & $\begin{array}{l}\text { A mudança desejada pode } \\
\text { ocorrer, mas se for desta } \\
\text { maneira pode ser superficial e } \\
\text { pode não ser duradoura. Além } \\
\text { disso ressentimentos podem } \\
\text { voltar a assombrar os } \\
\text { gerentes. }\end{array}$ \\
\hline
\end{tabular}

Fonte: Adaptado de Kotter e Schlesinger (1979, apud Palmer, Dunford e Akin, 2008)

Mesmo diante do que foi dito, autores como Giroux (1993, apud Silva, 2001) defendem que atribuir a maior parte das falhas das tentativas de implantação da mudança organizacional às resistências humanas é uma maneira reducionista de lidar com o problema. Isto porque para Kets de Vries e Balazs (1999, apud Silva 2001), muitos estudos da psicologia organizacional têm visto o indivíduo como simples recipientes de determinantes ambientais e adotando essa perspectiva, esses estudos negam a existência de um mundo 
interior repleto de desejos, anseios e fantasias. Além disso, tem se considerado os indivíduos como seres simplesmente racionais que mudam seus comportamentos de acordo com as informações que recebem e agem de acordo com seus interesses próprios. E as emoções, por sua vez, são tidas como irracionais, logo, não devem ser levadas em conta no mundo organizacional.

Os mesmos autores acreditam que pouca ou nenhuma atenção tem sido dada a estes processos internos e inconscientes que acontecem nos indivíduos durante o processo de mudança organizacional. Em contrapartida, alguns outros acreditam que a mudança organizacional está atrelada à capacidade de acontecer uma mudança individual, pois argumentam que apesar de tudo, as organizações são feitas de coleções de pessoas e para instituir uma mudança, deve-se entender as reações individuais do processo de mudança.

\subsubsection{Resiliência}

Resiliência é um termo científico, usado para classificar diversos materiais. O grau de resiliência de dado material significa o quanto de pressões externas, das mais variadas naturezas, ele pode absorver, sendo capaz de retornar à sua forma original. Levando para o lado humano do conceito, significa o quanto uma pessoa é capaz de sofrer estresses, absorvê-las e superá-las, sem desenvolver alguma disfunção comportamental.

No campo organizacional, segundo Barlach, Limongi-França e Malvezzi (2008), resiliência se refere à existência ou à construção de recursos adaptativos de forma que preservem a relação saudável entre o indivíduo e seu trabalho em um ambiente de mudança. Para Coutu (2002, apud Barlach, Limongi-França e Malvezzi, 2008) há três características básicas de organizações e pessoas resilientes: i) a firme aceitação da realidade; ii) a crença profunda, em geral apoiada por valores fortemente sustentados, de que a vida é significativa; e iii) uma grande habilidade por improvisar. Ainda segundo esses autores, uma outra característica forte em pessoas resilientes é a questão da positividade, que não se confunde com a distorção da realidade. Uma vez que, esse atributo possibilita ao indivíduo transcender à posição de vítima e de alguma forma ser capaz de tirar lições dos acontecimentos e situações advindas de tempos de crises. 


\section{Métodos e procedimentos de coleta e de análise de dados do estudo}

\subsection{Tipo de pesquisa}

O estudo é qualitativo de natureza descritiva. Para Gil (2002), as pesquisas de natureza descritiva têm como principal objetivo a descrição de características de determinadas populações ou fatos ou o estabelecimento de relações ou associações entre variáveis.

Sendo assim, o presente estudo se utilizou deste tipo de pesquisa, uma vez que visou relacionar as reações positivas ou negativas dos indivíduos em face da maneira com a mudança organizacional foi implantada.

As fontes são primárias e não se pretende utilizar de fontes documentais.

Como dito anteriormente, os comportamentos dos indivíduos no contexto da mudança organizacional tornam-se um tema criticado por certos autores por ser ainda pouco explorado pela academia, logo essa pesquisa também tem em vista levantar novas indagações e reflexões sobre essa temática.

\subsection{Sujeitos da amostra}

Os entrevistados são do tipo alvo, que pela definição de Conner (1995), são as pessoas que sofreram o processo de mudança, elas não são responsáveis por planejar ou comunicar, por exemplo, mas apenas sofrem o processo. Eles serão selecionados pelo critério de acessibilidade.

Esse conjunto é composto por 8 pessoas e a tabela a seguir reúne e classifica os sujeitos quanto à sua formação, sexo e tempo de trabalho:

Tabela 2 - Características do Sujeito da Amostra

\begin{tabular}{|c|c|c|c|}
\hline Entrevistado \# & Sexo & Formação & $\begin{array}{c}\text { Tempo de } \\
\text { Trabalho }\end{array}$ \\
\hline Entrevistada 1 & Feminino & Administração & 22 anos \\
\hline Entrevistada 2 & Feminino & Administração & 7 anos \\
\hline Entrevistada 3 & Feminino & Publicidade & 30 anos \\
\hline Entrevistada 4 & Feminino & Engenharia & 17 anos \\
\hline Entrevistado 5 & Masculino & Engenharia & 41 anos \\
\hline Entrevistada 6 & Feminino & Administração & 20 anos \\
\hline
\end{tabular}




\begin{tabular}{|c|c|c|c|} 
Entrevistada 7 & Feminino & Design & 33 anos \\
\hline Entrevistado 8 & Masculino & Administração & 26 anos \\
\hline
\end{tabular}

\subsection{Coleta de dados}

A coleta se deu por meio de entrevistas em profundidade com base em roteiro semiestruturado de 16 perguntas (pode ser consultado no apêndice), pois ao longo das entrevistas poderiam surgir pontos que não foram previamente pensados que agreguem à pesquisa. Os entrevistados foram pessoas que passaram em algum momento de suas vidas por uma mudança organizacional

Com as três primeiras perguntas buscou-se identificar o sujeito que foi perguntado sobre sua formação, seu tempo de trabalho no mercado e as funções exercidas ao longo de sua carreira (conforme Tabela 2 - Características dos Sujeitos da Amostra).

A partir da quarta pergunta, começou-se a questionar sobre a mudança organizacional vivenciada pelo sujeito. Sendo esta mesma questionando sobre qual mudança mais o impactou e em qual empresa o sujeito estava. A pergunta seguinte, questiona o motivo de este evento ter tipo o maior impacto na vida do sujeito.

Com a sexta pergunta pretendeu-se saber do que se tratou a mudança organizacional e tentar classificá-la segundo o que vimos na seção 2.1.1 do referencial teórico, "Classificações e Tipos da Mudança Organizacional". A sétima pergunta quis saber sobre quanto tempo a mudança durou até ser dada como terminada, se é que houve um fim.

A oitava questão foi sobre a comunicação da mudança e o sujeito foi questionado sobre como ele ficou sabendo que a mudança iria acontecer. Isto é importante saber, pois diversos autores, como vimos no capítulo 2, concordam que uma parte fundamental relacionada ao desempenho da implementação da mudança é a forma como ela é comunicada.

A nona questão quis entender como a mudança aconteceu e questionou sobre a existência ou não de etapas. Autores como Kotter (1997), por exemplo, acreditam que há um passo-a-passo para que a mudança seja bem implementada, então aqui pretendeu-se saber se o sujeito percebeu se a organização utilizou algum método de etapas para gerar a mudança.

A décima pergunta questionou o sujeito sobre fatos marcantes da mudança organizacional que ele vivenciou. Pois o sujeito pode não ter sido 
comunicado sobre a existência de etapas, porém pode ter percebido marcos que para ele seccionou o processo de mudança.

A pergunta número 11 teve como objetivo entender o nível de urgência percebido pelo sujeito. Para Kotter (1997), deve ser a primeira etapa da implementação da mudança: o estabelecimento do senso de urgência, conforme vimos na seção 2.1.2.3 no capítulo 2, "O Processo de Mudança em Oito Etapas de Kotter".

A décima segunda questão foi sobre a reação ou sentimento inicial que o sujeito teve ao saber que a mudança aconteceria. Aqui buscou-se fazer um paralelo com o que Kets de Vries e Balazs (1999, apud Silva, 2001) identificam como as principais fontes de resistência, caso a reação inicial fosse de resistência. A pergunta seguinte questionou se essa reação ou sentimento mudou ao longo do processo.

A pergunta 14 questionou sobre quem eram as pessoas responsáveis pelo processo de mudança acontecer e buscou-se identificar através dela os atores da mudança trazido por Conner (1995).

A pergunta seguinte, quis entender se o sujeito pode falar de suas reações, sentimentos ou percepções com os responsáveis pela mudança, pois conforme Conner (1995) fala, a pior forma de resistência a se vencer é exatamente a que não é manifesta. Logo, para o autor, gerentes inteligentes estimulam seus subordinados a trazerem à tona suas percepções, reações e sentimentos positivos, mas principalmente negativos.

A última pergunta quis saber se foi atribuída alguma responsabilidade ou participação ao sujeito no processo da mudança. Além disso, procurou-se entender o motivo da atribuição tanto no caso de resposta afirmativa quanto negativa. Esta questão se relaciona ao que Kotter e Schlesinger (1979, apud Palmer, Dunford e Akin, 2008) falam sobre os seis métodos para gerir a resistência, pois o segundo método, por exemplo, é exatamente a participação e envolvimento. Os autores defendem que quando as pessoas se tornam participativas na decisão é mais difícil que resistam às mesmas

\subsection{Tratamento e análise de dados}

As entrevistas foram gravadas e transcritas e tiveram um tempo médio de 40 minutos de duração.

Foi utilizada a técnica de tratamento de dados conhecida como análise de conteúdo que para Gil (2002) surgiu pelo grande volume de material produzido 
pelos meios de comunicação e a necessidade de interpretá-los. O autor diz que essa técnica pode ser utilizada tanto em estudos qualitativos, caso do presente estudo, como em quantitativos.

Segundo Gil (2002), a técnica se desenvolve em três fases: A primeira é chamada de pré-análise, onde são levantados documentos, formulação de hipóteses e é feita a preparação do estudo para a análise; a segunda fase, chamada de exploração do material, é constituída pela escolha das unidades de pesquisa, a enumeração e a classificação. A terceira e última fase é de inferências e interpretação de dados.

\subsection{Limitação do Método}

O método é subjetivo e os resultados da análise ficam inerentes à interpretação do pesquisador.

Além disso, outra limitação significativa deste método é que os resultados só podem ser considerados naquele universo entrevistado. Não podendo ser assumidos como verdadeiros para toda a população.

Como os entrevistados falaram de si e de seus comportamentos no contexto de mudança, suas falas não refletem fielmente o que aconteceu, pois o que pretende-se estudar é exatamente a percepção individual do sujeito no contexto de mudança organizacional, não entender o que de fato aconteceu, ou que estava previsto no papel que aconteceria. 


\section{Apresentação e Análise dos Resultados}

\subsection{Descrição do perfil dos entrevistados}

Foram entrevistadas 8 pessoas que passaram em algum momento de suas vidas por alguma mudança organizacional.

Com as três primeiras perguntas buscou-se identificar o sujeito, perguntado sobre sua formação, seu tempo de trabalho no mercado e as funções exercidas ao longo de sua carreira.

Os gráficos a seguir mostram esses dados de identificação dos indivíduos, como: sexo, área de formação e tempo de mercado. As funções exercidas por eles ao longo de sua carreira, assim como a área de atuação no momento da mudança será dita mais adiante:

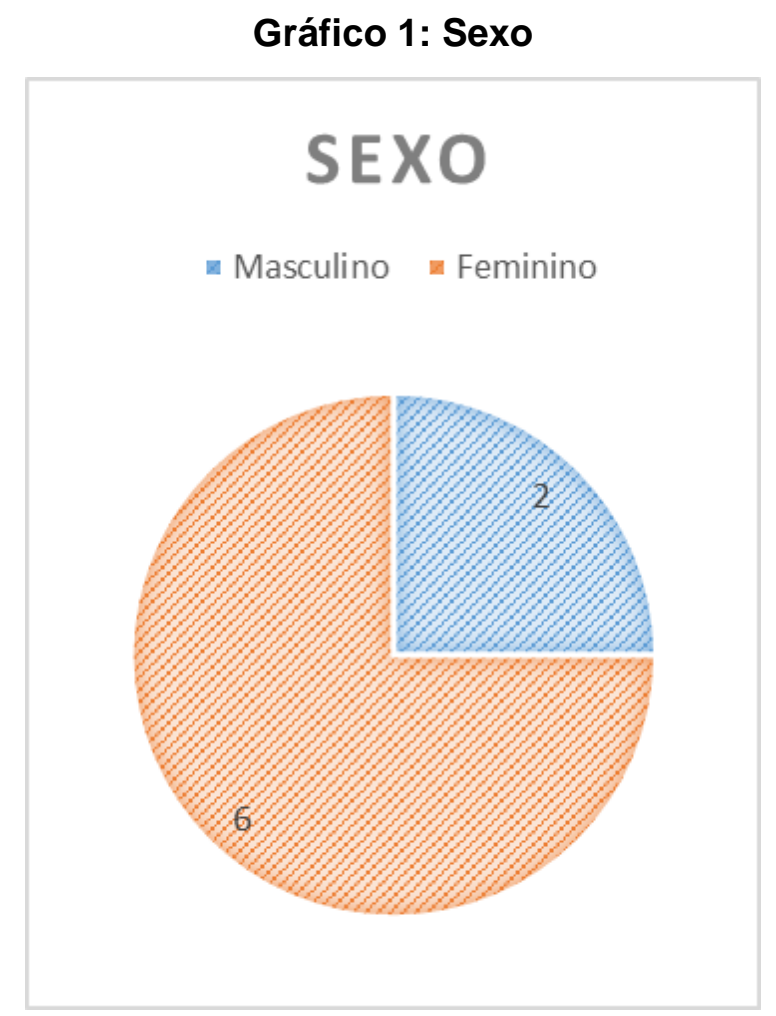

Observamos que $25 \%$ da amostra apenas é composto por homens, como falado anteriormente, o critério de seleção foi por acessibilidade e a maioria das pessoas alcançadas foram mulheres, resultado influenciado muito mais pelo círculo social da autora, do que por um outro motivo específico. 


\section{Gráfico 2: Área de Formação}

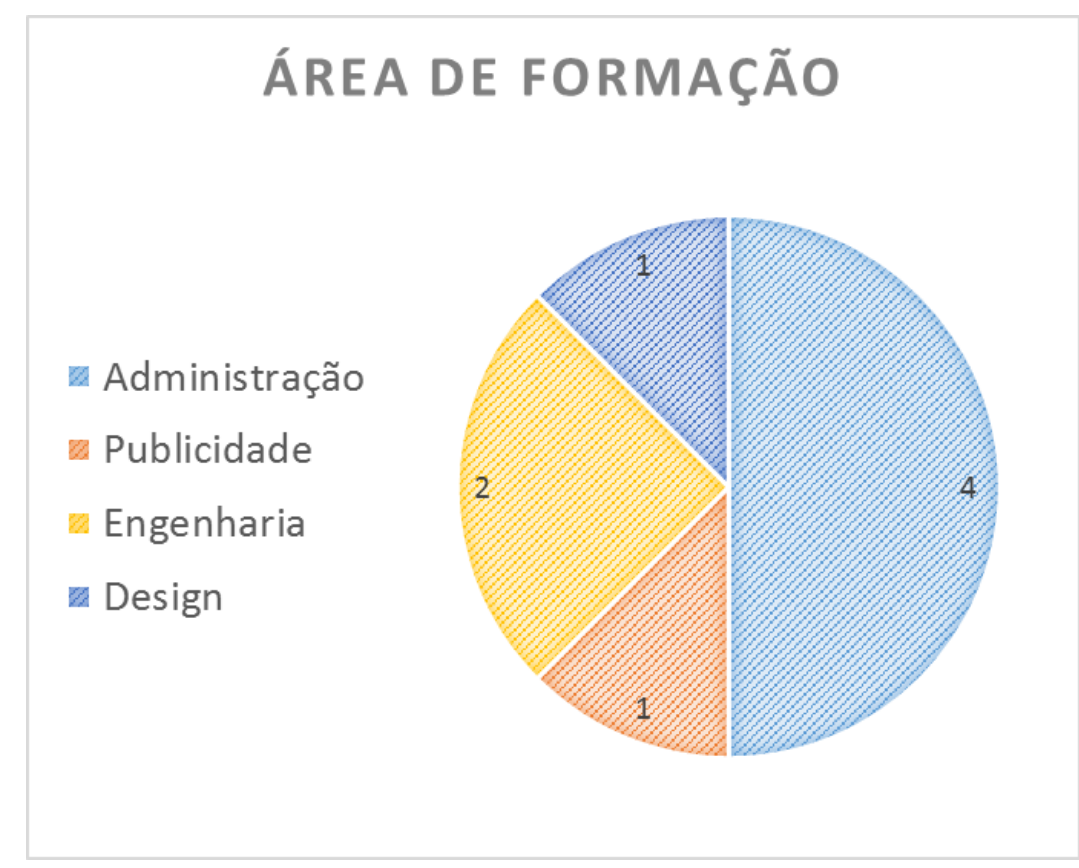

A maioria dos entrevistados é formada no curso de Administração, isso pode ser explicado pelo mesmo critério de acessibilidade e pelo ciclo social da autora. Há, porém, outras variedades de formação e não foi observado relação significativa entre o curso de formação do indivíduo e seu comportamento ante a mudança, sendo esses apenas dados de informação sobre os entrevistados.

\section{Gráfico 3: Tempo de Mercado}

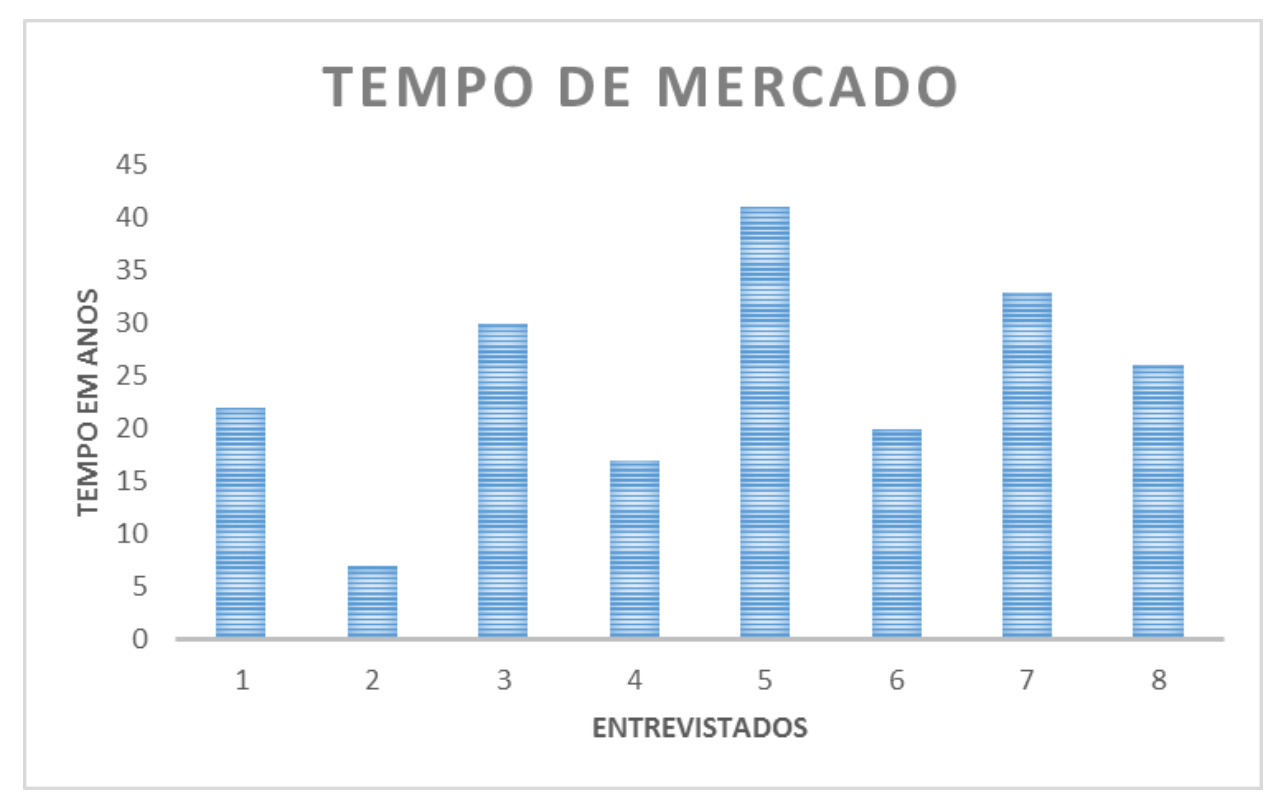

A média de tempo de mercado, em anos, dos entrevistados é de 24 anos de trabalho, ou seja, são pessoas que, em média, ingressaram no mercado de 
trabalho em 1992. Contudo, há alguns outliers como o Entrevistado 5 com 41 anos de mercado de trabalho e a Entrevistada 2 com sete anos de atuação.

\section{Funções Exercidas ao Longo dos Anos de Carreira:}

A Entrevistada 1 trabalhou em loja, depois foi bancária e trabalhou por muito tempo no departamento de Recursos Humanos $(\mathrm{RH})$, depois passou a ministrar aulas em universidades e em cursos corporativos. Atualmente continua dando aulas em universidade e trabalha na área de carreiras. Quando vivenciou a mudança organizacional que mais Ihe impactou atuava no departamento de Recursos Humanos de uma empresa.

A Entrevistada 2 começou sua carreira como estagiária do departamento de Relação com Investidores da empresa onde passou pela mudança que mais the impactou até então. Depois de efetivada, continuou atuando na mesma área e completou 6 anos na mesma empresa. Depois desse acontecimento, ela saiu da empresa e atualmente, ela atua na área de relacionamento com os investidores em uma empresa administradora de shopping centers.

A Entrevistada 3 tem a principal parte de sua carreira atuando no departamento de Recursos Humanos: ela começou como instrutora de $\mathrm{RH}$ e chegou ao cargo de diretora. Além disso ela dá aulas em cursos de pósgraduação.

A Entrevistada 4 trabalha há 13 anos em um instituto de inovação e de incentivo ao empreendedorismo ligado a uma universidade. Lá, ela exerce o cargo de gerente executiva e suas principais funções estão relacionadas à gestão em si do centro. Além disso, seu trabalho está ligado ao acompanhamento da gestão financeira, à formação de equipes que trabalharão em determinado projeto, auxílio no desenvolvimento de empresas nascentes, dar consultoria a empresas associadas, entre outros. Antes de chegar a esse instituto exerceu a sua profissão de engenheira civil e de produção, trabalhando no controle de obras.

O Entrevistado 5 trabalhou, nos primeiros quatro anos de sua carreira, no Serviço Federal de Processamento de Dados. Depois disso, entrou para uma empresa estatal no segmento de energia, onde atuou durante o restante da sua carreira até hoje. Nesta última empresa começou como técnico de computação, analista técnico e de negócio, líder de projetos, assumiu cargos de gerência e, atualmente, atua como consultor da presidência. 
Os primeiros dois anos da carreira da Entrevistada 6 foram no departamento de Recursos Humanos de uma empresa multinacional do ramo petrolífero na área de treinamento. Os 18 anos seguintes, atuou em uma empresa, também multinacional, de serviços de consultoria na área de gestão de projetos para pessoas. Esta área normalmente envolvia processos de transformação organizacional, gestão de mudança, processos de $\mathrm{RH}$, gestão de talentos, dentre outros, em diferentes indústrias.

A Entrevistada 7 trabalhou durante 20 anos no mercado da moda, como gerente de produto, desenvolvendo todos os produtos que tinham dentro de uma loja. Atuava desde a concepção do modelo, escolha de tecidos, definição do mix de produtos, até a orientação a franqueados. Depois, passou a ser coordenadora de eventos durante muito tempo e os últimos 9 anos atuou numa empresa multinacional de tecnologia e serviços. No início, nesta última empresa, ela atuou um curto período no banco que esta possui na área de Leasing, depois, ela conseguiu mudar para o departamento de marketing, onde passou a maior parte do tempo.

O Entrevistado 8 iniciou sua carreira profissional em uma instituição financeira que hoje já não existe mais, pois foi comprada por outra empresa. A sua última atuação no mercado foi como executivo de uma empresa de grande porte do ramo de telecomunicações. Além disso, desde 1995 ele atua como professor universitário.

\subsection{Descrição e análises dos resultados}

\subsubsection{Classificação e tipo de mudança organizacional}

O objetivo principal dessa pergunta foi entender em que contexto de mudança organizacional cada entrevistado estava envolvido. Eles foram estimulados a falar sobre o fato que Ihes causou maior impacto.

\section{Entrevistada 1: Criação de um Centro de Serviços Compartilhados}

A mudança organizacional vivenciada pela Entrevistada 1 foi em um grupo formado por empresas de rádio e jornal impresso e online, quando trabalhava no departamento de recursos humanos. Pretendia-se criar um Centro de Serviços Compartilhados (CSC) que atenderia a todas as empresas do grupo. Todas as áreas de backoffice como Recursos Humanos, Tecnologia da Informação, Financeiro e outras, de todas as empresas do grupo, seriam unificadas em uma 
nova estrutura de empresa que prestaria serviço ao grupo, para que as empresas pudessem focar em seu negócio core. O processo durou em torno de um ano, mas não se concretizou.

O tipo de mudança vivenciada neste caso, tendo por base o mapa mental de Tersine, Harvey e Buckley (1997, apud Silva, 2001), foi de ordem humana/social e é considerada uma mudança normal, pois se caracteriza como uma realocação de pessoal ou uma reorganização das áreas de backoffice em um CSC. É classificada como uma mudança intencional, pois houve uma intencionalidade da direção do grupo em implantar esse centro de serviços compartilhados, mesmo tendo sido percebido pela Entrevistada 1 como algo sem planejamento.

\section{Entrevistada 2: Mudança de Diretoria em Decorrência de Inúmeras Transformações Ocorridas na Empresa}

No caso da Entrevistada 2, a empresa onde atuava já vinha, ao longo de alguns anos, passando por uma fase de instabilidade e grandes transições, com o objetivo de tornar-se uma empresa mais enxuta:

"Eu entrei na empresa, num momento que já começou uma crise, em 2009, então eu já peguei corte de custos e redução de despesas, então, a empresa já vinha decaindo e mudando muito, então eu peguei um tsunami assim no momento que eu entrei, então não peguei uma época muito boa, peguei muitas pessoas frustradas que passavam isso para mim, então a minha insatisfação com meu trabalho lá começou muito cedo. Eu fiquei muitos anos lá e isso só foi acumulando". (Entrevistada 2)

Como consequência dessas transformações, alguns fatos ocorreram, dentre os quais: a saída do CEO, mudanças na diretoria, redução de custos e contenções de despesas, mudança de CFO por quatro vezes no período de 6 anos, mudanças de benefícios, etc. Dentre todos, o que mais lhe impactou foi a aposentadoria forçada do diretor de sua área, pois ela achava que:

“(...) ele era uma pessoa muito difícil de lidar, então, [a saída dele] era a oportunidade de melhorar tudo que achava que era errado, mas depois vi, na verdade, que ele não era a culpa de vários problemas e é mais fácil você lidar com o difícil conhecido do que com o novo". (Entrevistada 2)

Neste caso, a empresa onde a Entrevistada 2 atuava vinha passando por grandes transições de natureza humana, pois ocorria mudança tanto na maneira 
de trabalhar, como mudanças de presidente e diretores, políticas e regras, todas essas mudanças com caráter severo e realizadas de forma intencional.

\section{Entrevistada 3: Intervenção Policial, Crise Financeira e Reestruturação}

O Entrevistada 3 atuava em uma empresa de varejo quando sofreu uma intervenção da Polícia Federal, fato desencadeador de muitas mudanças. Esta ação resultou, principalmente, em uma grave crise financeira que quase levou a empresa à falência, houve muitas demissões e um clima de grande instabilidade. Após receber financiamento externo, a empresa conseguiu se recuperar e como consequência precisou se reinventar e, em resumo, mudar de uma cultura paternalista para uma cultura meritocrática.

Desde a intervenção policial, até a sua total recuperação, foram quatro anos. Para a Entrevistada 3, o maior impacto foi ter que participar deste momento como diretora de $\mathrm{RH}$, função que sempre foi seu objetivo a ser atingido:

"Eu era diretora de $R H$ da empresa de varejo e ela sofreu uma intervenção da polícia federal e eu, na verdade, estava no cargo há um mês, [antes] eu era gerente, meu diretor saiu da empresa. (...). Basicamente nessa mudança, a empresa quase faliu. Depois ela foi comprada, depois a gente ajudou também nesse processo de retomada. Foi um momento muito tenso, a empresa tem uma cultura organizacional muito forte, em geral, era uma empresa muito querida pelos funcionários, então quando as pessoas viram aquele movimento, elas se mobilizaram muito em função da causa de não deixar a empresa morrer". (Entrevistada 3)

As demissões que ela teve que fazer também foram muito impactantes como pode ser visto a seguir:

"E eu me lembro que para mim foi muito marcante, o dia que nós demitimos essas 1200 pessoas sem nenhum tipo de problema. Eu recebi uma mensagem de parabéns do presidente e eu chorei muito com aquela mensagem, na época a gente usava torpedo. Eu chorei para caramba, eu já tinha naquela altura 24 anos de trabalho e eu não queria ser reconhecida como a diretora de $\mathrm{RH}$ que demitiu 1200 pessoas e não causou nenhum tipo de problema..." (Entrevistada 3)

Esse episódio se caracteriza como ações legais significativas contra a organização do mapa mental de Tersine, Harvey e Buckley (1997, apud Silva, 
2001), pois possui natureza humana e social e caráter severo. Foi não intencional, pois não era esperada, nem prevista, aconteceu em decorrência de um fator externo que desencadeou o processo.

\section{Entrevistada 4: Mudança de Diretoria e Perda de Autonomia}

A Entrevistada 4 já trabalhava há mais de 10 anos com o seu diretor, quando ele avisou que iria se aposentar e seu objetivo era prepará-la para que ela assumisse o cargo em seu lugar. Porém, ao contrário do que era esperado, a reitoria da universidade decidiu por colocar uma pessoa diferente no cargo. A surpresa maior para ela não foi esta decisão em si, pois ela já estava preparada para essa possibilidade. O que mais the surpreendeu foi o perfil do escolhido que não era alguém de dentro da universidade e nem do setor de empreendedorismo.

A maior mudança que este novo diretor trouxe e que lhe causou maior impacto foi a perda de autonomia percebida por ela, pelas demais gerentes e pela equipe:

"Além de ele estar mais presente, porque o antigo diretor viajava muito, tinha muita representatividade, reuniões... esse novo diretor, além de estar mais presente, o que é bom, ele tem uma forma de trabalhar diferente: Ele quer se envolver em tudo, tudo o que for gasto tem que passar por ele, tem que ter aprovação dele, ele tem que assinar, ele tem que entender, senão ele não assina. Então, isso acabou tirando um pouco da autonomia, principalmente, das gerentes, minha e das outras gerentes." (Entrevistada 4)

\section{Entrevistado 5: Expansão e Encolhimento}

O Entrevistado 5 viveu dois momentos marcantes de transformações que ocorreram na empresa estatal do segmento de energia que ele trabalhava. $A$ primeira grande transformação, aconteceu no início do milênio e tinha como motivação a criação e expansão de novas linhas de negócios, além da internacionalização dessas novas linhas para outros países. A segunda grande mudança, em oposto a primeira, tem por objetivo o encolhimento da empresa e vem acontecendo atualmente.

\section{Entrevistada 6: Reorganização da Orientação de Trabalho}

A empresa em que atuava a Entrevistada 6 é uma consultoria multinacional e, segundo ele, contava com uma área de gestão da mudança 
mais avançada. A transformação sofrida na organização, que durou 6 meses, foi na forma como a empresa orientava seus serviços: antes, era orientada por segmentos de indústria e depois, passou a ser orientada por funcionalidade. Passados 15 anos, a empresa retornou para um modelo muito similar ao primeiro, orientado por segmentos de indústria, essa segunda mudança ainda está acontecendo.

A Entrevistada 6 vivenciou esses dois momentos de transformação, a primeira, teve mais impacto em sua vida e sobre isso relatou:

"Então, o que eu vi de mais positivo foi o desenvolvimento dos funcionários na linha das especialidades, treinamentos, troca de experiências, gestão do conhecimento. Esse foi o lado positivo. Eu acho que o lado mais desafiador, foi a gente ter que sair de um modelo, onde a gente já era bastante conhecido, em termos de desempenho, de relacionamento e networking interno e ter que reconstruir tudo isso, dentro dessa nova área. Aí as pessoas eram diferentes porque vieram de múltiplas industrias, a gente teve que refazer os vínculos, os relacionamentos, aprender a nova forma de trabalho, uma liderança bastante diferente..." (Entrevistada 6)

Esta foi uma mudança de natureza humana/social e de caráter normal, podendo ser considerada como uma reorganização. Foi intencional e foi planejada pela liderança global.

\section{Entrevistada 7: Reestruturação do Departamento de Marketing}

A Entrevistada 7 trabalhava em uma empresa multinacional de tecnologia e serviços no momento em que houve uma reestruturação de todo o departamento de Marketing, onde ela atuava até ser desligada da empresa por conta de um corte decorrente desta reestruturação.

O departamento que antes era único para toda a empresa, passou a existir em cada uma das cinco linhas de negócio da empresa e a ser orientado por cada uma delas.

Além disso em cada linha de negócio havia dois times de marketing: um que lidava com as vendas e outro com as ações para o mercado. O primeiro estava junto com o time de vendas, ouvindo-os e conhecendo a sua demanda, eles determinavam qual o produto seria o foco da temporada; e outro que recebia as demandas e realizava as ações para o mercado, desenvolviam a melhor forma de colocar aquele produto no mercado. Outra grande transformação foi a redução das próprias linhas de negócio que começaram a 
deixar de existir ou a se mesclarem entre si quando havia alguma semelhança entre elas, o que resultou em fechamento de escritórios e redução de pessoas:

"Essa foi a maior mudança na maneira de trabalhar. Inicialmente eles mudaram a organização e depois eles mudaram a maneira de trabalhar e aí resultou em enxugar também os cargos". (Entrevistada 7)

As transformações vêm ocorrendo ao longo de dois anos e ainda não se consolidaram. Essa mudança foi intencional de natureza humana social, foi uma reorganização das linhas de negócio e uma realocação de pessoal nos dois times que surgiram no departamento de Marketing, ela teve intensidade normal.

\section{Entrevistado 8: Reestruturação em Decorrência a Duplicidade de Cargos}

A empresa do setor de telecomunicações que o Entrevistado 8 atuava, tinha como foco a telefonia fixa, mas fazia parte de um grupo que reunia uma empresa de telefonia móvel, eram empresas distintas, com culturas diferentes e operações separadas. Em determinado momento, decidiu-se por juntar as operações fixa e móvel, gerando uma duplicidade de cargos por causa de um contingente maior de pessoas.

Isto a princípio, não foi preocupante, pois a empresa estava em um processo de expansão e se preparava para a aquisição de uma companhia do mesmo setor e, por conta disso, haveria certo espaço para alocação dessas pessoas. Porém, a companhia a ser comprada, tinha como controladora do grupo a que pertencia, uma empresa norte americana que estava falida e com uma dívida grande com o dono de uma empresa concorrente à empresa em que o Entrevistado 8 trabalhava. Como pagamento da dívida, a controladora e todo o grupo foi adquirido pela tal concorrente e a transação esperada não aconteceu.

Com isso, não houve mais espaço para tantas pessoas e cargos, então houve uma grande reestruturação que durou em torno de 3 anos.

\subsubsection{Estruturação da mudança e marcos do processo}

A mudança vivenciada pela Entrevistada 1 não tinha nenhum tipo de estruturação em etapas ou planejamento percebido, pelo contrário, segundo ela:

"A sensação que a gente tinha era que resolveram assim vamos pensando junto... Vamos fazendo pensando!". Após o anúncio da mudança, o jornal, empresa mais forte do grupo, teve a responsabilidade de investigar e estudar como unificar as áreas 
pares de todas as empresas do grupo neste centro de serviços compartilhados. Os funcionários já eram considerados como parte desta nova unidade, mas continuavam no mesmo espaço físico: "Primeiro eles decidiram fazer e foram querer fazer esses estudos depois. Aí que se começou a ver que tinha muita coisa para unificar, diferente de você unificar uma política de compras, você tinha que unificar tudo. Salário: a rádio paga abaixo do mercado, o jornal paga acima do mercado, tudo bem então agora a gente pode dizer que vai pagar todo mundo acima? Mas isso quer dizer que você vai aumentar o salário de todo mundo da rádio? E não, mas a rádio não tem estrutura para comportar: 'ah então a gente vai trabalhar com duas tabelas?' Então, nada disso foi pensado, aí quando começou a se levantar isso, as pessoas foram meio que se cansando, era tanta coisa para fazer..." (Entrevistada 1)

Até como uma consequência dessa falta de planejamento claro, um fato marcante para a Entrevistada 1 foi a primeira questão que surgiu com o anúncio da criação do CSC:

"Essa foi a primeira mudança, então todo mundo ficou, assim: 'ah então, mas e agora? Como é que vai ser? A gente vai sentar aonde? ' A primeira coisa era essa: a gente vai continuar sentado onde a gente senta? Por que a gente ficava sentado dentro da empresa. A gente vai para outro lugar que todos os do CSC vão ficar junto ou a gente vai ficar com as outras empresas do grupo? Então a primeira coisa era saber onde a gente ia ficar". (Entrevistada 1)

Outro fato marcante era que o presidente do jornal era contra o processo de criação do centro de serviços compartilhados e fazia de tudo para dificultar a criação dessa nova área:

"Ficou uma queda de braço entre o presidente da empresa e esse grupo [de criação do CSC]. Só que esse grupo, veio de uma diretriz da organização. Mas não tinha uma pessoa especifica que era assim, o pai daquilo ali. A própria pessoa que ia ser a presidente, estava assim: 'ah vamos ver se isso dá certo. A primeira reunião que ela teve com a gente ela disse assim: "Ah, vamos tentar para ver se dá certo. Assim, não era uma coisa que a gente percebia que era assim: ela está emprenhada, vai dar tudo certo, a gente está caminhando..." (Entrevistada 1) 
Essa falta de coalização administrativa, citada por Kotter como uma das etapas de implementação da mudança, acabou gerando outros problemas neste processo. O presidente do jornal conclui que se todas as áreas de backoffice seriam separadas da empresa, seria então necessário que houvesse uma pessoa dentro da empresa para se relacionar com o CSC e contratou uma gerente de Recursos Humanos para fazer essa intermediação:

"E aí, ele contratou uma pessoa que trabalhava na rádio, era gerente de $\mathrm{RH}$ da rádio, aí começou a ficar meio estranho, 0 que era para diminuir, aumentou a estrutura, chegou mais uma pessoa para o $\mathrm{RH}$, mais as pessoas que já estavam no $R H^{\prime \prime}$. (Entrevistada 1)

A nova contratada também começou a dificultar a criação do CSC, alegou que não conseguiria trabalhar sozinha e começou a contratar outras pessoas para compor o seu time local, foi quando começou uma divisão entre pessoas que eram locais e pessoas que eram remotas, que iriam para o CSC, mas que continuavam na antiga estrutura da empresa.

Como podemos observar, não houve uma estruturação ou um plano de gestão de mudança como proposto pelos autores aqui estudados. Como falado pela Entrevistada 1, eles decidiram que iam criar o centro de serviços compartilhados e somente depois foram estudar como fazer e confirmar a viabilidade deste processo.

No caso da Entrevistada 2, durante os seis meses seguintes ao anúncio da aposentadoria do seu chefe, as coisas continuavam como se nada tivesse acontecido:

"Nesse meio tempo não houve nada para que a gente tenha se programado a para mudança, a gente estava trabalhando como se nada tivesse mudado, até porque, sei lá se ia acontecer..." (Entrevistada 2)

Um fato marcante para ela aconteceu bem próximo da saída efetiva do seu diretor: Todo final de ano a empresa oferecia algum tipo de curso ou treinamento com professores de universidades estrangeiras a seus funcionários. Aproveitando esta oportunidade, o gerente da sua equipe convidou um professor para que pudesse conversar com a equipe e prepara-los para o novo momento que viveriam:

"Ele [o diretor] saiu em janeiro, aí em dezembro ele [o gerente geral] chamou uns professores do curso para falar com a equipe 
sobre a mudança. Porque chegou um momento que era mês que vem, daqui duas semanas, a gente vai chegar e vai ter outro cara aqui, ninguém conversou com a gente. Foi ideia do gerente geral na época, e sentamos toda a equipe para conversar com esse cara [o professor convidado]. E a gente foi falando porque a gente estava nervoso, das frustações, o que a gente esperava da mudança, tudo isso. A pessoa traz uma perspectiva muito diferente, a gente conversava com as pessoas mais próximas, a gente não sabia a opinião do gerente geral, por exemplo. Aí acaba que todo mundo fica sabendo das frustações e angustias, pelo menos a gente conseguiu se expressar, só que não foi iniciativa do $\mathrm{RH}$, ou da empresa, ou do CFO, foi uma iniciativa da equipe, foi o gerente e a gerente geral que propuseram. " (Entrevistada 2)

O fato marcante está diretamente relacionado a esta falta de preparação para a nova realidade que estava se aproximando, mas tudo estava como era antes. Veremos mais a frente que esta falta de planejamento e de saber o que seria do futuro causou muita ansiedade.

O departamento de Recursos Humanos da Entrevistada 3 tentou desenhar um plano de gestão de mudança, mas o que ela percebia era que as coisas aconteciam tão rápido e tão instantâneo que não era possível segui-lo:

"Na época, uma pessoa da minha equipe estudou aquele modelo do congelar e descongelar, aí ela montou um plano, planejou várias ações de comunicação interna. A gente aprovou com o presidente o plano, mas eu diria que a gente ficou com ele em mente uma semana ou duas, mas não deu, porque era tudo muito rápido, você não sabia, você estava fechando um planejamento, uma coisa, aí alguém vinha e dizia: 'Não dá mais, isso aí o juiz da recuperação judicial vetou, tem que ter outra ideia, a gente foi muito empírica, não teve um processo estruturado de gestão de mudança." (Entrevistada 3)

Apesar disso, houve diversos fatos marcantes e o primeiro deles foi o que desencadeou todo o processo: a intervenção policial na empresa, sobre isto ela comenta: "Então o primeiro dia foi um marco, foi o dia que caiu a ficha, de que estava acontecendo algo muito grave e a gente teve que assumir 0 controle, pelo menos no aspecto da gestão de pessoas. ". 
Outro marco para ela foi a mobilização para pagar a folha de pagamento dos funcionários, com todos os recursos da empresa bloqueados, não seria possível pagar os funcionários. Na visão dela, não pagar os funcionários seria um primeiro indicativo de que a empresa estava falindo, além do risco de roubo de mercadorias nas lojas por parte dos funcionários:

"A gente fez um mutirão, pensar nisso hoje parece até loucura. A gente começou a pegar todo o dinheiro em espécie que vinha das lojas e ao invés de mandar para o banco, a gente trazia para a matriz, e fazia: 'ah hoje chegou dois milhões, isso dá para pagar a folha de x lojas'. Aí a gente separava aquele dinheiro, ia para a agencia do banco, normalmente um funcionário da área financeira e um segurança, se a gente colocasse dinheiro na conta da empresa, a polícia confiscava, [...] Levava a folha de pagamento e o gerente ia depositando o dinheiro, isso fez com que as pessoas recebessem antes, então tem um ciclo positivo, porque imagina se você está com dúvida se ia receber 0 salário no dia, você receber um ou dois dias antes". (Entrevistada 3)

Para ela, esta foi a primeira sinalização de que a empresa poderia se manter de pé.

Outro fato marcante foi o desligamento de 1200 funcionários, espalhados em 50 lojas, que aconteceu em um único dia. Para ela foi neste momento que houve mais planejamento: montou-se um script para cada gerente de loja que deveria fazer o anúncio da demissão em equipe. Houve uma preocupação especial e o gerente que não se sentia preparado pode ter o auxílio de algum funcionário do $\mathrm{RH}$.

A negociação com os 22 sindicatos sobre o aumento salarial anual que não ia acontecer também foi um fato marcante. Como a empresa estava em recuperação judicial, no lugar de aumento salarial, a proposta era aumentar os benefícios dos funcionários. Essa proposta foi negociada por quatro meses e teve cerca de $90 \%$ de aprovação por parte dos funcionários.

O último fato que lhe marcou foi a construção do modelo meritocrático, antes a empresa possuía uma cultura paternalista.

No caso da Entrevistada 3, segundo ela, a velocidade com que aconteciam as mudanças não possibilitaram a criação de um plano de gestão de mudança, muito também pelo fato de não ter sido uma mudança deliberada, mas sim, não intencional, decorrente de uma intervenção policial, a princípio, não esperada 
pela empresa. As decisões sobre o que poderia ser feito estavam também muito atreladas ao que o processo de recuperação judicial lhe permitia fazer ou não.

Para a Entrevistada 4, a preparação para a aposentadoria de seu antigo diretor e posterior assunção de seu cargo, vinham acontecendo durante os 6 meses anteriores à decisão da reitoria de trazer uma pessoa de fora para assumir o cargo de direção.

Com a nova decisão, não houve nenhum tipo de etapa ou de preparação para o novo cenário que se desenhava:

"Não houve nenhuma etapa. Como havia te falado, sabíamos da mudança, mas a expectativa era outra. Soubemos da mudança [de decisão] em dezembro e em janeiro começamos a fase de transição. Nada foi muito conversado antes disto. Não tínhamos muita informação sobre o novo diretor e na época da transição o antigo diretor começou a se afastar nos deixando inseguros. Como havia mencionado os diretores são bem diferentes e fazem gestão de forma distintas. A etapa de transição na minha opinião teria que ser acompanhada por alguém do RH e não ser tão solta como foi." (Entrevistada 4)

Não houve por parte da alta direção um plano para conduzir esta transição. Para ela, um fato marcante inclusive, foi que antes de se aposentar, seu antigo diretor, propôs a criação de um conselho interno, onde ele participaria por um tempo, afim de transformar este momento de transição em algo mais suave e não em uma grande ruptura, mas esta proposta foi recusada pelo novo diretor:

"Ele [ex-diretor] queria montar um conselho interno que ele participasse, até na tomada de decisão, para tentar manter o 'core' e de certa forma a filosofia e a cultura do Instituto. E a primeira coisa que o novo diretor disse, era que não queria isso. Que não queria a permanência do ex dentro do Gênesis, então isso pra gente foi assim... a gente não imaginou que ele ia dizer: 'Não, não precisa'.

A gente imaginou que a pessoa ia dizer: 'Ok, então fica e vamos passando isso aos poucos'. Então isso na verdade foi uma ruptura muito forte para nós todos. Muito do dia para a noite, então a gente teve essa ruptura. [...]. Porque quando a gente conversou, antes a gente até falou: a gente faz de uma forma light, leve, para a gente entender, aí ele falou: 'É eu vou estar próximo, vou estar no conselho de vocês, vamos tentar trabalhar isso...' Então isso de 
certa forma, para a gente, foi um pouco impactante também." (Entrevistada 4)

Segundo o Entrevistado 5, todo o processo de mudança que acontece na empresa estatal onde ele atua, sempre possui algum tipo de metodologia de gestão de mudança associado. Tanto o processo de expansão e internacionalização que a empresa viveu em 2000, quanto o processo de enxugamento que está vivendo atualmente, foram acompanhados por uma consultoria nos primeiros meses que fornece a metodologia a ser seguida:

" $E$ aí, isso também faz parte da cultura da companhia, essa consultoria externa que chega para ajudar e assessorar, na prática, 0 que ela faz é fornecer a metodologia de trabalho, quer dizer, todo esse processo de etapa, como as coisas vão ser registradas, como vão ser conduzidas, como vão ser deliberadas" (Entrevistado 5)

O processo de mudança na empresa da Entrevistada 6 contou com um plano desenhado pela matriz fora do Brasil que foi posteriormente avaliada pelas lideranças brasileiras quanto à sua viabilidade. Tendo sido aprovado, foi então desenhado uma estratégia de gestão de mudança.

A primeira etapa foi a comunicação da mudança pelas lideranças, depois quando a área foi lançada, houve a etapa em que as pessoas puderam contribuir em seu detalhamento, trazendo ideias de como a área iria funcionar. A última etapa foi a de implementação das rotinas do dia a dia, na qual os funcionários também puderam participar na construção dos mecanismos de funcionamento, na rotina de reuniões, na sugestão de outros critérios de avaliação que poderiam existir na nova área, além dos já existentes na empresa, entre outros.

Para a Entrevistada 6, esta estruturação foi um dos fatores que garantiu a facilidade na condução do processo:

" $A$ estruturação da mudança é muito importante. Todo esse planejamento da mudança foi muito bem feito, o engajamento das pessoas foi muito trabalhado, sempre partindo do topo." (Entrevistada 6)

Um fato marcante para ela é a insegurança que aparece no primeiro momento que surge a notícia que haverá uma mudança. O momento seguinte de entendimento da nova área a ser formada e a oportunidade percebida por ela de se desenvolver dentro de uma funcionalidade e ter seus objetivos pessoais de encontro com a proposta da mudança, foram também marcantes. Além disso, os 
funcionários que quiseram manter-se na estrutura antiga, também tiveram esta oportunidade:

"Então no fundo não teve tanto impacto negativo, teve positivo e uma insegurança natural. Porque todo processo de mudança traz uma insegurança que é inerente ao processo." (Entrevistada 6)

No caso da Entrevistada 7, as etapas de implementação da nova mudança foram mais voltadas para a nova forma como ia se trabalhar no departamento por meio de treinamentos. Para ela, o mais marcante foi de ter que absorver mais trabalho e o clima posterior às demissões:

"Eu acho que a gente ter que absorver mais trabalho, impacta seu trabalho diretamente, e é muito chato você ver pessoas que você trabalhava sendo mandada embora, cria um clima muito esquisito. Agora depois de todas as demissões que aconteceram no marketing, o clima do time fica muito esquisito, fica horrível. As pessoas começam a trabalhar com medo, quem vai ser a próxima?' (Entrevistada 7)

Segundo o Entrevistado 8 a reestruturação que a empresa de telefonia fixa passou teve várias etapas, por ter sido um processo muito grande e mais drástico, mas que ele não consegue bem se recordar.

Porém há alguns marcos que ele se recorda bem, como, por exemplo, a demissão de 31 diretores no mesmo dia. Para ele, isso ficou marcado, pois foi um processo de desligamento que começou pela parte executiva da empresa, o que trouxe uma resposta positiva da equipe. Segundo ele, há uma maior reação negativa quando as demissões começam pela base da empresa, que pode não fazer tanta diferença, quanto quando os cargos mais altos são cortados: "Se você quer gerar uma mudança mesmo, uma transformação, você tem que ir na cabeça". (Entrevistado 8)

Outro marco importante foi saber que durante o processo de reestruturação, seu cargo havia sido extinto e ele estava na expectativa de ser alocado na nova estrutura que estava sendo proposta pela consultoria. E, finalmente, um último grande marco para ele foi o espírito de companheirismo que surgiu ao fim do processo. 
Nesta seção procurou-se analisar a percepção das etapas de implementação da mudança organizacional pelos indivíduos. Muitas vezes, na ausência de etapas, podem ser percebidos marcos de podem demonstrar uma transição de um momento para o outro, em muitos depoimentos esses marcos são explicitados com muitos sentimentos envolvidos.

Como relatado na maioria dos casos, a estruturação dos processos de mudança não foi algo claramente percebido pelos indivíduos. Em relação as Entrevistadas 1 e 2, depois do anúncio da mudança, parecia que nada ainda havia mudado e nem sabia se algo ia acontecer. Já no caso da Entrevistada 3, houve uma tentativa de planejamento que não teve êxito por causa da velocidade que os fatos iam ocorrendo, porém houve muitos marcos relacionados a evolução do processo. A Entrevistada 4 estava estruturando o instituto onde ela atua para a aposentadoria de seu diretor e se preparando, de certa forma, para uma mudança, porém ela não esperava que quem assumiria o cargo, seria uma pessoa tão a parte da sua realidade. A empresa onde o Entrevistado 5 atua, tem a cultura de em todos processos de mudança, contratar uma consultoria externa, que fornece toda a metodologia e os planos desenhados. Da mesma forma, o momento de mudança vivenciado pela Entrevistada 6, em uma consultoria de negócios, contou com um plano e uma estruturação em etapas que para ela foi fundamental para o sucesso da mudança. A Entrevistada 7 teve várias etapas de treinamento e preparação para o novo modelo de trabalho que lhe seria apresentado. O Entrevistado 8 não consegue se recordar, mas acredita que com certeza houve um plano, por conta da importância que o processo teve.

A seguir, um resumo da estruturação dos processos vivenciados:

\section{Tabela 3 - Estruturação Percebida}

\begin{tabular}{|c|l|}
\hline Entrevistado \# & \multicolumn{1}{|c|}{ Estruturação da Mudança } \\
\hline Entrevistada 1 & Não houve estruturação percebida \\
\hline Entrevistada 2 & Não houve estruturação percebida \\
\hline Entrevistada 3 & Não foi possível montar um plano estruturado \\
\hline Entrevistada 4 & Não houve estruturação, houve uma grande ruptura \\
\hline Entrevistado 5 & Houve estruturação desenhada por uma consultoria externa \\
\hline
\end{tabular}




\begin{tabular}{|c|l|}
\hline Entrevistada 6 & Houve estruturação \\
\hline Entrevistada 7 & Estruturação relacionada a etapas de treinamentos \\
\hline Entrevistado 8 & Não se recorda, mas acredita que houve \\
\hline
\end{tabular}

A estruturação e o planejamento da mudança são importantes, pois garantem ao indivíduo certa previsibilidade do que irá acontecer e isso contribui para reduzir as inseguranças e contribuem com o grau de controle que o indivíduo possui sobre a situação. Como diz Conner (1995), quando a necessidade de controle é atendida, reduz-se o desconforto da insegurança.

\subsubsection{Comunicação da mudança}

A primeira tática proposta por Kotter e Schlesinger (1979, apud Palmer, Dunford e Akin, 2008) para gerir ou minimizar o desconforto trazido por processos de mudança organizacional é a educação e a comunicação. O objetivo delas é fazer com que os indivíduos entendam o que acontecerá no momento de transição que a empresa vivenciará ou está vivenciando. Esse entendimento é importante pois também contribuirá para atender o que Conner (1995) chama da necessidade dos indivíduos por controle. Isso Ihes traz certa previsibilidade e consequentemente reduz o desconforto das incertezas.

O modo que se comunica a mudança, na visão de Kotter (1997) é tão importante que antes mesmo da implementação das oito etapas, é necessário que haja uma liderança de alta qualidade capaz de criar uma visão clara de longo prazo, comunicada com palavras e com ações às pessoas que, por sua vez, compram a ideia por terem sido inspiradas e motivadas pela liderança.

A Entrevistada 1 ficou sabendo que a mudança ia acontecer através de uma reunião geral com todos os funcionários. Após isso cada departamento, em separado, teve outra reunião para falar sobre a criação do centro de serviços compartilhados. Houve também um anúncio ao mercado geral, o quadro de avisos e jornal interno da empresa também foram utilizados, além de e-mails falando sobre a criação desta nova unidade.

Já nesta primeira reunião pôde-se encontrar um problema na comunicação da mudança, pois segundo ela, a pessoa escolhida para assumir a presidência da nova unidade não demonstrou, em seu pronunciamento, interesse, nem segurança para a condução do processo: 
"A pessoa que ia levar não demostrou ter muito interesse, porque ela mesmo falava: 'Ah! Se não der certo a gente volta como está... no primeiro dia que você vai comunicar uma mudança você diz se não der certo! " (Entrevistada 1)

Além disso, a comunicação foi feita apontando-se os ganhos econômicos para a empresa, baseados em estudos feitos e em casos de sucesso de outras empresas:

"Decidiu- se fazer isso, se achou muito bom, fizeram um estudo... mas o estudo era assim: quanto vai se ganhar? Em termos de economia. Mas não pensaram, em termos de mudança, isso dentro da empresa. Porque as pessoas estavam acostumadas a serem atendidas por um RH dentro de uma empresa, e essa pessoa do $\mathrm{RH}$ é uma pessoa de dentro da empresa, os executivos, os gerentes, estão acostumados a pedir coisas pro $\mathrm{RH}$, como é que ia ser essa operação no dia a dia? Não pensaram. Pensaram: Ah vai ser legal? Vai. Vamos economizar? Vamos. É uma boa ideia? É uma boa ideia. Aí resolveram implantar." (Entrevistada 1)

Nitidamente, não houve a comunicação clara da visão de longo prazo da mudança, dos objetivos que seriam alcançados, ou como seriam. Além disso, é importante que a liderança através de suas palavras e ações inspire e motive os funcionários, o que também não aconteceu.

No caso da Entrevistada 2, a saída de seu chefe foi comunicada por ele mesmo na reunião semanal da equipe. Outras mudanças, no entanto, eram comunicadas por um clipping diário:

"Tinha o clipping diário com as notícias da empresa e você lia: sua empresa agora é assim. Mas a sua vida não mudava, a não ser quando você perdia um benefício, poucas reuniões, como a empresa é grande também..." (Entrevistada 2)

A comunicação da mudança para a Entrevistada 3 era feita através de canais oficiais, tais quais: quadros de avisos, e-mail e ouvidoria interna, esta tratava-se de um telefone celular que fica 24 horas por dia com funcionários do Recursos Humanos que iam revezando-se entre si. Também eram usados canais não oficiais, como: redes sociais e conversas informais com outros 
departamentos. A organização contratou uma empresa de comunicação especializada em gestão de crise que, para ela, teve um papel importante para manter os funcionários informados.

Uma das ações desta empresa contratada foi a identificação dos "funcionários formadores de opinião", segundo a Entrevistada 3 eram pessoas que se estivessem convencidas de algo, seriam capazes de convencer os demais de sua equipe. A estratégia funcionava da seguinte forma: o departamento de Recursos Humanos ia até as lojas para reunir a equipe e atualizá-los sobre a situação da empresa, após o termino, esses formadores de opiniões eram reunidos separadamente do resto da equipe e eram provocados a fazer perguntas ou tirar dúvidas. Eram pessoas que o departamento acreditava que sairia daquela reunião para fazer comentários negativos, então eles tentavam antecipar esses comentários e saná-los com essa segunda reunião somente com eles. Não havia um critério explícito para a escolha desses formadores de opinião, elas tinham a características de serem bem ouvidas por seus pares, ou muito tempo de carreira, ou pessoas que no passado possuíam certo poder que foi perdido ao longo do tempo, mas que mantiveram suas relações e seu poder de influência, por exemplo.

Houve uma situação em que os funcionários queriam fazer uma mobilização no centro de distribuição numa segunda-feira, isto foi identificado pela empresa de comunicação por meio das redes sociais dos funcionários no sábado anterior. Com isso, o departamento de Recursos Humanos pôde contatar os funcionários e conversar com eles sobre alguma dúvida que eles quisessem resolver antes do dia marcado para a manifestação.

A Entrevistada 4 soube da mudança na decisão sobre quem assumiria a direção do instituto quando seu antigo diretor se aposentasse, diretamente por ele:

“A princípio, assim, não me pegou de surpresa porque eu já imaginava que viria em uma pessoa diferente. O meu ex-diretor queria que eu virasse a diretora e ele estava fazendo tudo pra isso, mas na minha cabeça eu sabia que sempre poderia vir outra pessoa de fora, até por conta da política da universidade e ele fez questão de me falar por conta disso, porque ele recebeu até mais com impacto do que eu" (Entrevistada 4)

Os responsáveis pela decisão de mudança, a reitoria da universidade da qual o instituto faz parte, porém, não deixaram claro o motivo de tal decisão. 
Segundo ela, durante os 6 meses antes da notícia, seu antigo diretor, a estava preparando para assumir seu cargo, isto já tinha até sido aprovado pelo conselho administrativo do instituto, porém no final desse período foi anunciado que outra pessoa assumiria o cargo:

"A reitoria tinha outros interesses políticos, não sei se políticos ou estratégicos, que também não deixou claro para gente. Na época, deram uma explicação que a pessoa que tava vindo, vinha um pouco para ajudar em outros projetos da Universidade, então a gente não entendia muito bem porque estava caindo aqui, mas foi a única explicação que deram pra gente. E que no final, na verdade, não aconteceu, porque ela não cuida de outros projetos da Universidade, ela cuida só do Genesis, não ficou muito bem explicado. $O$ fato é que não foi muito bem passada essa informação para a gente." (Entrevistada 4)

A visão a ser alcançada pela reitoria com a mudança na decisão sobre quem iria assumir a diretoria não foi bem comunicada ao instituto e aos seus funcionários. Ao analisar a fala da Entrevistada 4, o maior impacto na comunicação não foi pelo fato da mudança da diretoria em si, mas pela maneira como ela foi conduzida, sem que revelassem os motivos pelo qual houve essa troca repentina, depois de meses de preparação.

Segundo o Entrevistado 5, há na empresa estatal onde ele trabalha, uma cultura de preparação para uma mudança organizacional. Em relação à forma como a comunicação é feita, ele diz que são formados grupos de gestão de mudança que tem como único objetivo, manter as pessoas informadas dos fatos que acontecem na empresa:

"São facilitadores, na verdade, são pessoas de $R H$ ou de áreas correlatas, como de comunicação, de organização e gestão, que constituem um grupo com um único intuito de manter as pessoas informadas do que está acontecendo e dos impactos que elas vão sofrer. Então isso já era prática." (Entrevistado 5)

Ainda segundo ele, quando os acontecimentos tiveram maiores impactos na empresa, a comunicação foi feita para todo a empresa em auditórios, por exemplo.

A Entrevistada 6 foi comunicada a respeito da mudança organizacional inicialmente pelas lideranças diretas. Posteriormente, dependendo do grau de transformação que as mudanças trariam à rotina dos funcionários, haviam outros 
tipos de comunicação, como em grupo, por exemplo. Cada etapa era comunicada à equipe, houve a comunicação do aceite da proposta do projeto de mudança, houve a comunicação do novo líder da equipe, este reuniu a equipe ao assumir o posto e efetuou um processo de comunicação muito bem estruturado, segundo ela:

"Esse novo líder fez um processo de comunicação bastante estruturado, então dentro de um processo de mudança, um dos pilares mais importantes é essa comunicação, quando mais cedo a gente souber, quanto mais clareza houver no processo, mais fácil fica a condução. $E$ isso acho que foi muito bem feito neste processo. "Ainda sobre a comunicação, a Entrevistada 6 falou: "quando a gente não é muito efetivo na comunicação a rádio peão é. Entre essa notícia [de que haveria uma reorganização] e de fato alguma formalização, sempre começam aquelas discussões e boatos, etc." (Entrevistada 6)

Durante a primeira parte da mudança que a Entrevistada 7 vivenciou, a separação do departamento de marketing em dois times, ela afirma que só soube da mudança depois que aconteceu, apesar disso, haviam algumas evidências de que algo estava acontecendo:

"A gente começa a ouvir de que ia mudar pra dois times de marketing... A gente começa a ter algumas palestras, são 'calls', como eles chamam, sobre mudança organizacional, aí começa a ter rumor de corredor... Algumas mudanças, essa especificamente, por exemplo, a gente só soube depois que ela aconteceu. Você tinha um 'felling' que a coisa estava mudando, de que algum gerente ia rodar, mas aí foi mais assim." (Entrevistada 7)

Quando houve a estruturação do departamento por áreas de negócios, segundo ela, as transformações foram mais graduais e mais informadas, ao longo do ano houve diversos chamados para treinamentos sobre a nova maneira de se trabalhar o marketing na empresa.

O Entrevistado 8 não se recorda de um processo estruturado de comunicação. Segundo ele, sua liderança direta sempre o mantinha bem informado das mudanças que estavam acontecendo e das esperadas e ele como gerente de equipe também procurava mantê-la, da mesma forma, bem informada. 
"Eu tava muito informado, eu trabalhava na matriz, [...] meu chefe era um cara muito bacana, muito aberto. Eu não me lembro se o processo de comunicação foi o mais adequado possível, [...] meu chefe me informava: 'Olha, eles contrataram uma consultoria, estão construindo uma estrutura' [...] Com certeza, a comunicação que meu chefe fez comigo, que na minha diretoria eu tinha acesso, fez uma diferença muito grande" (Entrevistado 8)

A comunicação da mudança está intimamente ligada à criação da visão de longo prazo do processo, o que por sua vez, está relacionado ao planejamento e à estruturação da mudança. Não havendo este último, fica difícil haver uma comunicação clara de onde pretende-se chegar. A tabela a seguir mostra, resumidamente, a percepção dos entrevistados quanto à comunicação da mudança.

Tabela 4: Comunicação da Visão de Longo Prazo

\begin{tabular}{|c|l|}
\hline Entrevistado \# & \multicolumn{1}{|c|}{ Comunicação da Visão } \\
\hline Entrevistada 1 & Não houve uma comunicação da visão efetiva \\
\hline Entrevistada 2 & Divergência entre o discurso e a prática \\
\hline Entrevistada 3 & $\begin{array}{l}\text { Canais formais e informais. Contratação de empresa } \\
\text { especializada. }\end{array}$ \\
\hline Entrevistada 4 & Não houve uma comunicação da visão efetiva \\
\hline Entrevistado 5 & Através de grupos constituídos como facilitadores \\
\hline Entrevistada 6 & A comunicação foi feita por sua liderança direta \\
\hline Entrevistada 7 & A comunicação não foi clara e explícita \\
\hline Entrevistado 8 & A comunicação foi feita por sua liderança direta \\
\hline
\end{tabular}

Outro ponto de atenção que surge em alguns casos é o fato dos rumores e da chamada rádio corredor, ou seja, dos canais informais de comunicação que acontecem dentro da empresa, algo que é pouco falado pelos autores aqui estudados, mas que são de grande representatividade nos processos de mudança organizacional. 


\subsubsection{Participação e responsabilidades}

A Entrevistada 1, atuava no departamento de Recursos Humanos na área de Remuneração, sua responsabilidade no processo de implementação do CSC era inerente à função que ela exerceria:

"Eu tinha responsabilidade em unificar o processo, eu fazia os estudos, então ia na editora, aí fui algumas vezes em São Paulo, na rádio. Porque eu tinha que estudar as políticas para propor e analisar os impactos financeiros, para escolher uma. A minha responsabilidade era ver qual eram as melhores políticas. A rádio tem uma melhor política aqui nesse aspecto de remuneração, de benefícios, ah então vamos ficar com esse aqui. [...] $A$ minha responsabilidade era fazer esses estudos, apresentar e a partir dali decidir com qual ia seguir, e fazer o estudo de viabilidade. " (Entrevistada 1)

Para ela, esta responsabilidade Ihe foi atribuída, puramente por já ser uma rotina de sua área:

"A remuneração é o financeiro do $\mathrm{RH}$, a gente cuida muito de orçamento, cuida dos indicadores, relatórios, estudo. Então já é uma área que faz isso, então acho que era o natural da minha área. Não foi assim, porque eu fui a escolhida, foi a minha área, então eu tive que fazer. " (Entrevistada 1)

A Entrevistada 2 não teve nenhuma responsabilidade sob qualquer processo de transformação que aconteceu em sua empresa. Para ela, foram sempre ações que vinham do topo da organização e eram impostas a ela:

"Nenhuma (responsabilidade). Porque foi top down, não engajaram as pessoas na mudança [...]. Às vezes eles chamavam os gerentes para reunião, para disseminar aquela mensagem, o que vai mudar, eu não era gerente, então eu me sentia sempre a parte. Isolada. A mudança acontecia e eu era só a espectadora ali que tinha que me adaptar. " (Entrevistada 2)

Ela também conta que na escolha do novo diretor da sua área a equipe não foi em momento nenhum consultada: "Quando escolheram o novo diretor, ninguém veio falar com a equipe, potenciais candidatos, qual era nossa opinião, não queriam nem saber. " (Entrevistada 2) 
Outro exemplo citado por ela confirmava seu sentimento, a empresa queria testar uma nova forma de avaliação dos funcionários, uma espécie de avaliação $360^{\circ}$ : "[...] era uma 360 que não era 360, porque o gestor não era avaliado pelos subordinados... o diretor não era avaliado pela equipe. Isso é um exemplo muito claro de que a nossa opinião não valia muito. "(Entrevistada 2)

A Entrevistada 3, diz que, no primeiro momento em que estourou a crise, ninguém the atribuiu alguma responsabilidade específica no processo da mudança, mas o presidente interino lhe disse que a partir do momento em que ela decidiu permanecer na empresa era necessário que ela desse tudo de si naquele momento de mudança. Ela tinha, porém, responsabilidades inerentes ao departamento de Recursos Humanos, como a de fazer as demissões, por exemplo.

Já num segundo momento, quando a empresa começou a dar sinais que iria sobreviver à crise financeira, com a chegada de um novo diretor geral, lhe foram atribuídas responsabilidades mais associadas à construção da nova cultura, como o desenvolvimento de um plano de metas, alinhado a essa nova cultura meritocrática que desejava-se formar.

A entrevistada 4 teve certa participação no processo de mudança, pois como falado, ela estava sendo preparada para assumir o cargo e com isso, também tinha a tarefa de estruturar o instituto para receber esta nova diretoria:

"Eu tive, na verdade, porque quando teve o movimento de transição lá atrás quando o ex-diretor falou que ia se aposentar, ele me chamou e queria que eu fosse a substituta dele... A universidade me chamou para fazer um coaching, o RH achou bom que eu fizesse o coaching, já que eu ia ser a substituta dele. Durante o meu coaching do $\mathrm{RH}$ eu sempre levantava a hipótese de: não serei eu a pessoa a ser a diretora. Porque eu tinha lá no fundo, um sexto sentido, que tudo poderia acontecer, mas de qualquer maneira, eu simplesmente comecei a estruturar de certa forma o Instituto, para ser uma coisa mais transparente para a Universidade" (Entrevistada 4)

Quando há processos de mudanças mais impactantes na empresa estatal em que o Entrevistado 5 atua, é comum que se constituam grupos que dominam determinado assuntos para auxiliar no processo da mudança e, no encolhimento 
que a empresa está atualmente passando, ele faz parte de um grupo que faz proposições para a área de gás natural da companhia.

No primeiro caso, de expansão da empresa, como a sua área era fortemente impactada pelas transformações que ocorreriam, ele também teve certa participação e envolvimento no processo.

Assim também aconteceu com a Entrevistada 6, ela disse que não tinha responsabilidade total sobre o processo, mas ajudou na construção da nova área, na condução do grupo à migração para o novo cenário, na distribuição das pessoas e na comunicação às pessoas. Além disso, como citado antes, houve uma preocupação da empresa em ter uma etapa onde as pessoas puderam contribuir na construção dessa nova realidade:

"Todo esse planejamento da mudança foi muito bem feito, 0 engajamento das pessoas foi muito trabalhado, sempre partindo do topo, então a liderança engajada e participativa durante 0 processo, transmite confiança e engajamento para as pessoas, transparência nas mensagens, isso dá muito segurança e ajuda muito, oportunidade de participação do grupo que estava passando pelo processo na construção desse novo cenário, dentro da possibilidade, nem sempre é possível. O que foi possível houve." (Entrevistada 6)

A Entrevistada 7 não considera que teve participação significativa no processo de mudança:

"A nossa responsabilidade era absorver, aprender $e$ performar. A gente não era muito participativo não, porque nenhuma mudança foi proposta pela gente, nada disso. Não, a gente tinha só que absorver, performar e ver como seria a melhor maneira da nossa equipe trabalhar, mas dentro daquilo que foi proposto." (Entrevistada 7)

O Entrevistado 8 teve dificuldade em lembrar de sua participação no processo de mudança, mas depois comentou uma grande participação que teve junto com seu gerente, após a chegada da telefonia móvel e antes que ele tivesse seu espaço na nova estrutura. Ele montou um projeto de estruturação da sua nova área e nesse estudo ele mesmo reconheceu que seu cargo não teria mais sentindo, levando até a proposta da extinção dele, que depois aconteceu 
de fato, para a substituição por três outras pessoas que trariam mais agilidade à área por um custo de pessoal menor.

Os autores Kotter e Schlesinger (1979, apud Palmer, Dunford e Akin, 2008) defendem que quando há oportunidade para os indivíduos participarem e contribuírem para o novo cenário é mais difícil que eles resistam às transformações, além disso é também uma prática fundamental da teoria do desenvolvimento organizacional. Este ponto ficou a desejar em alguns casos citados, apesar da Entrevistada 1 ter um trabalho diretamente ligado à colaboração do novo cenário, ela não se sentiu contributiva, mas sim, como se fazendo o que era de sua rotina. A Entrevistada 2 sentia como uma espectadora, que só recebia a informação da mudança e tinha que se adaptar. Já a Entrevistada 6 atribui a facilitação da condução do processo, dentre outros fatores, à importância dada à etapa de envolvimento das pessoas na construção do novo cenário. A Entrevistada 7 também não tinha participação nenhuma no processo de mudança, senão ao que ela mesmo fala de absorver e performar.

A tabela seguinte resume as percepções dos entrevistados em relação à sua participação ou responsabilidades no processo que viveram:

Tabela 5 - Participação e Responsabilidades Percebidas

\begin{tabular}{|c|l|}
\hline Entrevistado \# & \multicolumn{1}{|c|}{ Participação ou Responsabilidade } \\
\hline Entrevistada 1 & Inerente à função que já exercia \\
\hline Entrevistada 2 & Nenhuma participação ou responsabilidade \\
\hline Entrevistada 3 & Sim, na fase final do processo \\
\hline Entrevistada 4 & Sim, na fase de estruturação \\
\hline Entrevistado 5 & Sim \\
\hline Entrevistada 6 & Sim \\
\hline Entrevistada 7 & Nenhuma participação ou responsabilidade \\
\hline Entrevistado 8 & Sim, pontual. \\
\hline
\end{tabular}

A falta do engajamento das pessoas no processo da mudança de maneira geral não gerou uma situação que impedisse o processo de acontecer, ou que fosse extremamente nocivo a ele, porém os sentimentos e as percepções das 
pessoas tendem a ser menos negativas quando elas podem contribuir com 0 cenário em construção.

\subsubsection{Abertura com os líderes}

A Entrevistada 1 não tinha abertura com as lideranças para falar de suas percepções ou sentimentos sobre o processo que a vinha afetando, como relata:

"Empresa em geral você não tem muito espaço pra falar, as pessoas até perguntam: 'Ah, e aí? Alguém quer falar alguma coisa? 'Mas é pra você falar que não." (Entrevistada 1)

Algumas reclamações e insatisfações da Entrevistada 2 eram até levadas ao seu antigo diretor, que quando tinha a mesma opinião da equipe, levava o assunto adiante, porém quando as opiniões divergiam, não eram levadas:

"A gente conversava muito entre a gente e isso já era muito bom, a gente discutia, e refletia, pensava em alternativas, e era muito difícil levar isso adiante e isso mudar alguma coisa, poucas vezes a gente conseguiu através do nosso chefe chegar até o nosso CFO". (Entrevistada 2)

O diálogo com o departamento de Recursos Humanos da empresa também era infrutífero segundo ela:

"Alguns casos a gente até chamava o pessoal do $\mathrm{RH}$, mas você via que eram mensageiros, que não tinham autonomia de mudar nada [...] Não tinha pra quem reclamar nesse aspecto, só para ele ou entre a gente". (Entrevistada 2)

A Entrevistada 3 conta que falava mais de seus sentimentos e percepções com a sua equipe e com pessoas que tinha mais afinidade:

"Para as pessoas que trabalhavam diretamente comigo, era muito tranquilo eu falar dos meus sentimentos, eram pessoas que eu já trabalhava há muito tempo, então a gente tinha uma relação de confiança boa, era uma equipe fantástica, agora as outras pessoas, os gerentes, os diretores, aí eu não falava. Primeiro porque eu não tinha tanta afinidade e tinha muita preocupação de que eles se espelhassem na gente, então nesse momento o RH é um espelho, então se a gente mostrasse muita fragilidade, eu ia perder essa conexão". (Entrevistada 3) 
A Entrevistada 4, quando perguntada se teve abertura para falar com as lideranças responsáveis pela tomada de decisão sobre a mudança, respondeu o seguinte:

"Não, na verdade não. A gente tem algumas percepções que a gente teve, até em forma de brincadeiras e piadas que não necessariamente são percepções legais, mas a gente não levou para frente. [...] a gente não viu muito apoio para levar. Hoje, a gente não sente um certo apoio da forma que é feito. Então a gente está dando tempo ao tempo pra tentar entender como é que vai ser esse processo." (Entrevistada 4)

O Entrevistado 5 teve certa abertura com sua liderança e pôde, em algumas ocasiões, questionar sobre as práticas do processo que discorda e muitas vezes era convencido, depois de entende-la melhor, de que ela era necessária. Para ele, toda mudança é difícil e uma das coisas que ele aprendeu com o tempo de trabalho é que o melhor é assimilar e aos poucos ir executando.

A Entrevistada 6 relata que sempre teve abertura com as lideranças com as quais trabalha, em alguns momentos mais abertura, em outros, menos:

"A primeira grande mudança, como eu também participava muito da discussão sobre a criação dessa nova área, eu tinha total abertura para falar qualquer assunto. Eu acho que foi muito transparente. Ao longo dos anos, em função do tipo da mudança, não tive tantas oportunidades, porque a mudança é essa e veio, é aquilo, tem que fazer, não tem muito o que ficar remoendo, tem que absorver e incorporar aquela mudança e fazer aquilo acontecer [...].Toda vez que acontecia uma coisa assim era muito complicado, porque a gente queria questionar, o porquê daquela mudança, muitas vezes você não tem muito acesso, a coisa já vem pronta." (Entrevistada 6)

Para a Entrevistada 7, falar de suas percepções não iria mudar o que estava acontecendo:

"Falar a gente pode falar, mas e daí? Não vai mudar nada. Não ia mudar o que estava acontecendo se a gente falasse alguma coisa. Poderia falar com meu gerente? A gente podia falar, mas 
assim, o processo não deixaria de acontecer ou nem seria diferente por causa da nossa percepção. É top-down mesmo." (Entrevistada 7)

O Entrevistado 8 diz que ele tinha abertura com alguns líderes, principalmente com um vice-presidente que apesar de ter sido alocado na nova estrutura, acabou saindo da empresa. Com ele, o Entrevistado 8 pôde questionar, de forma pontual e discutir se algumas práticas eram realmente as melhores a serem feitas, por exemplo. Ele disse também que com este vicepresidente, poderia ser mais reflexivo quanto ao processo, porém eram apenas conversas, muito mais informais.

Diante disso vemos que as lideranças das Entrevistadas 1, 2, 4 e 7 não incentivaram a discussão que Conner (1995) propõe quando diz que líderes inteligentes estimulam diálogos sobre o que tem incomodado os funcionários alvos da mudança, considerando que o pior tipo de comportamento resistente a ser resolvido é o implícito.

\section{Tabela 6 - Abertura com a Liderança}

\begin{tabular}{|c|l|}
\hline Entrevistado \# & \multicolumn{1}{c|}{ Abertura com a Liderança } \\
\hline Entrevistada 1 & $\begin{array}{l}\text { Acredita que empresa, em geral, não há muito espaço para } \\
\text { expressar sua percepção. }\end{array}$ \\
\hline Entrevistada 2 & $\begin{array}{l}\text { Tinha abertura para falar sobre o trabalho, não muita } \\
\text { abertura para falar sobre o processo. }\end{array}$ \\
\hline Entrevistada 3 & Procurava não falar, para não mostrar insegurança. \\
\hline Entrevistada 4 & $\begin{array}{l}\text { Acredita que não tem apoio para levar suas percepções } \\
\text { adiante }\end{array}$ \\
\hline Entrevistado 5 & Sim \\
\hline Entrevistada 6 & Sim \\
\hline Entrevistada 7 & $\begin{array}{l}\text { Acredita que o processo não mudaria por conta de sua } \\
\text { percepção, então nada adiantaria levá-las a sua liderança }\end{array}$ \\
\hline Entrevistado 8 & Sim \\
\hline
\end{tabular}

No relato dos participantes cujas reações e percepções foram negativas, não houve nenhum tipo de comportamento de boicote, houve reações negativas que não foram bem administradas pela liderança, muitas vezes pela falta de 
comunicação da visão, falta de coalização da liderança, falta de torna-los mais participantes do processo.

Os principais sentimentos negativos causados foram: frustração, angústia, ansiedade, insegurança, pressão por mais produção nas mesmas condições.

\subsubsection{Percepções, sentimento e reações}

Para a Entrevistada 1, sua primeira reação foi de avaliar se aquilo seria uma oportunidade ou uma ameaça à sua função, ela também citou a preocupação, apreensão e a expectativa em saber até que ponto aquela mudança iria lhe atingir. Conforme o tempo ia passando, ela começou a ter muita ansiedade, pois não havia uma definição de que caminho o CSC ia tomar, uma vez que os funcionários designados para trabalhar lá continuavam no mesmo lugar físico e tinham cada vez menos trabalho para fazer:

"Vamos mudar? Vamos unificar os salários? Ninguém decidia nada e você via que do outro lado, tudo estava sendo decidido a empresa continuava funcionando normalmente, e você estava sendo cada vez menos - a pessoa que atendia ao CSC - estava sendo cada vez menos necessária para a empresa. Porque a empresa começou a se estruturar de uma forma que não precisasse de pessoas do CSC, e aí? Vai ter ou não vai ter?" (Entrevistada 1)

A insegurança também era um sentimento presente e era causada pela falta de uma liderança forte na condução do processo:

"Eu tava vendo que aquele barco tava meio furado, porque eu tava vendo que nem a principal executiva estava falando assim: 'Ah vai dar tudo certo, a gente vai conseguir, vai ser difícil, mas a gente vai conseguir'. Não, ela falava: 'Pode ser que dê certo e pode ser que não e se não der...." (Entrevistada 1)

Outro ponto que a incomodou muito foi o surgimento do termo "zona cinzenta", como passaram a chamar aquelas pessoas que tinham tanto tarefas locais, como tarefas do CSC:

"Eu não gostei de ser zona cinzenta. Você fica meio assim: era zona cinzenta porque ninguém pensou em mim. Porque aí era uma coisa pessoal, devia ser assim: a atividade que você faz ou é uma coisa ou outra. Como eu atendia a empresa e fazia coisas que era meio corporativas, eu fazia as duas coisas, mas ninguém pensou em alguém que ia fazer as duas coisas, então é ruim porque você 
fala assim: ninguém pensou em mim. Então eu sou cinzenta?

\section{[...]. Eu comecei a me sentir mal." (Entrevistada 1)}

Nota-se que primeiramente houve a falta de um planejamento ou estruturação do processo de implementação deste centro de serviços compartilhados, ou pelo menos a falta da comunicação clara dos objetivos e das metas do processo. Até como falado na seção de "Estruturação da mudança", a sensação da Entrevistada 1 era que ia se fazendo e pensando, não foi percebido um plano prévio. Para que isso não aconteça, Kotter (1997) propõe que sejam estabelecidas metas de curto prazo para que o indivíduo possa perceber que 0 processo está caminhando e que com seu trabalho está se chegando a algum lugar.

A falta de uma liderança forte para a condução do processo também teve forte impacto na sua percepção sobre a mudança da Entrevistada 1. A liderança tem o papel importante em transmitir uma mensagem que irá inspirar e motivar os indivíduos para a mudança, neste caso, aconteceu justamente o contrário, a forma como foi transmitindo gerou insegurança e desmotivação.

O sentimento de ter sido esquecida dentro da nova estrutura também the causou muito desconforto e reforça o fato de a empresa não ter tido a preocupação de envolver as pessoas no processo de construção do novo cenário e não conseguiu passar para a Entrevistada 1 a sua importância na nova realidade.

Com o anúncio da saída no antigo diretor, a Entrevistada 2 ficou inicialmente muito animada, pois achava que essa seria a solução dos maiores problemas que ela via na empresa:

"Eu fiquei muito animada, eu achava que essa era a solução, que eu ia ter um gás novo, uma motivação maior, que as minhas frustações com a empresa e com ele, iam acabar. Eu achava que eu ia conseguir ser engajada novamente na empresa, então eu fiquei muito animada." (Entrevistada 2)

Mas, ao longo do tempo, esse sentimento positivo foi se transformando em angústia e frustração, atribuído por ela à demora na escolha do novo diretor e pela falta de informação sobre o andamento da escolha.

Quando finalmente esta escolha foi feita, a sua reação não foi positiva, pois, segundo ela, a pessoa para ocupar o novo cargo deveria ter experiência de mercado ou muito conhecimento sobre a empresa, atribuições que o novo diretor não possuía: 
"Contrataram um cara que não tinha experiência com 0 mercado de capitais e não trabalhava na empresa, então o que me irritava era que a empresa vendia uma ideia, um valor, de que ela valoriza as pessoas, era até um valor, valorizamos nossas pessoas. Eu falei: 'não, não é! É desvalorizamos!'. Por que não promover alguém de dentro? Porque fica naquela se não promovem ninguém pro cargo dele, eu nunca vou ser promovida quando tiver oportunidade, e isso foi me desanimando." (Entrevistada 2)

Como no primeiro caso, a demora para que algo acontecesse foi um fato gerador de angústia. Além disso, outro ponto importante é a falta de alinhamento entre discurso e prática percebida pela Entrevistada 2 quando ela aponta a divergência entre o valor da empresa e a ação de contratar alguém de fora. Para Kotter (1997), é necessária por parte da organização uma comunicação franca e confiável por meio de palavras e ações, para o autor a última tem maior peso, pois palavras podem ser esquecidas, mas ações, dificilmente. Claro que a empresa em questão pode ter tido seus motivos para a contratação, porém foi algo negativamente marcante para a Entrevistada 2 neste momento de transformações.

A Entrevistada 3 estava em seu novo cargo há um mês e inicialmente ficou chateada com a notícia da mudança:

"Primeiramente, eu fiquei muito chateada porque para mim, ser diretora de $\mathrm{RH}$ era um objetivo de carreira, aí com um mês de ter alcançado esse objetivo me acontece um negócio desse." (Entrevistada 3)

Como no caso da primeira entrevista, ela fez uma avaliação sobre os impactos positivos e negativos que aquele evento teria em sua vida, decidiu-se por ficar na empresa e fazer daquela situação a melhor possível:

"Eu fiz uma opção de ficar, eu vou mapear os riscos e fazer dessa situação, a situação mais maravilhosa que for possível, eu hoje, olhando para trás, posso dizer que eu consegui." (Entrevistada 3)

No decorrer do tempo, quando ela começou a perceber que a empresa dava sinais de melhoras e de que era capaz de se recuperar, começou a aproximar-se do presidente e mostrar que ele poderia contar com ela também no momento de retomada, porém ele achou melhor trazer um diretor de fora para esta tarefa, o 
que Ihe causou certa frustração e perguntada se ao longo do tempo esses sentimentos mudaram, responde:

"Mais ou menos um ano depois de ter começado o episódio, ele trouxe um diretor de $\mathrm{RH}$, me chamou e falou: 'Eu trouxe esse diretor de $R H,[\ldots]$ porque agora a gente já tem uma grande chance de não morrer, a empreitada agora é reconstruir, [...] eu não estou seguro de que você vai ser capaz de conduzir essa reconstrução, então eu trouxe uma pessoa que eu tenho certeza que vai ser capaz.'. É outro banho de água fria, você fala assim: 'Caramba! '. Ele falou: 'Eu não vou te demitir, você vai permanecer, mas eu não posso arriscar. Eu acho que se eu tivesse no lugar dele, eu tomaria a mesma decisão. " Mesmo diante desta situação, ela não se rendeu: "Se ele botou esse diretor, eu vou provar para esse diretor, que eu sou capaz, e eu ia aprender com ele. Graças a Deus, ele é uma pessoa muito aberta, e três meses depois ele chegou à conclusão que ele poderia fazer outras coisas, porque eu ia dar conta".

Esta decisão Ihe foi gratificante porque, segundo ela, desta vez conseguiu provar que era capaz e que depois disso os sentimentos foram muito melhores.

Nota-se fortemente no comportamento da Entrevistada 3 mediante a tal situação algumas características que Coutu (2002, apud Barlach, LimongiFrança e Malvezzi, 2008) identifica em organizações e pessoas resilientes, como, por exemplo, a firme aceitação da realidade na decisão que ela toma de continuar na empresa mesmo tendo considerados todos os riscos. Outra característica que se assemelha é a questão da positividade, que não se confunde com a distorção da realidade. Para o autor, esse atributo possibilita ao indivíduo transcender a posição de vítima e de alguma forma ser capaz de tirar lições dos acontecimentos e situações advindas de tempos de crises, o que pode ser claramente observado no comportamento dela ao querer provar por duas vezes que era capaz de se manter na posição que estava, não se fazendo de vítima ou se sentindo injustiçada, mas até se dispondo a aprender com a situação.

Esse comportamento pode ter sido atribuído à experiência de trabalho que teve previamente e à maturidade adquirida, ao fato de estar no departamento de Recursos Humanos e considerar o departamento como espelho para os funcionários e evitar esboçar percepções negativas para os outros funcionários, ao desejo de se realizar como diretora do departamento, cargo que tanto almejava, por exemplo. 
A Entrevistada 4 conta que inicialmente sua reação foi de surpresa com a nova decisão vinda da reitoria:

"Como eu já imaginava que vinha outra pessoa, eu já tava esperando... Eu fiquei um pouco surpresa, sim, mas de certa forma eu já imaginava, então não fiquei magoada, chateada, nada disso. [...] O que deixou a gente realmente surpresa é que era alguém totalmente fora da universidade, não era do ramo, do setor de empreendedorismo e era muito diferente da gente. [...]. Aí com a surpresa você fica um pouco mais insegura, com receio, vem outras questões junto." (Entrevistada 4)

Para ela, as percepções sobre a mudança de diretoria ainda se mantem: "Em termos de surpresa a gente não tem mais, já aconteceu, mas em termos de mudança e impacto, sim, essa percepção continua." (Entrevistada 4)

As percepções negativas apresentadas pela Entrevistada 4 parecem vir advir muito mais do fato de como foi conduzido o processo de decisão sobre a mudança do que pelo fato em si. Apesar de estar sendo preparada para assumir a direção, ela sempre acreditou na possibilidade de ter outra pessoa em seu cargo potencial, porém não era esperado que viesse uma pessoa tão diferente do que elas estavam acostumadas a trabalhar. Por ser um processo muito recente, sua maior insegurança é no quanto esse diretor vai afetar na essência do instituto, já que ele demonstra uma mentalidade muito diferente da atual:

"É uma pessoa diferente, e a gente obvio tá se adaptando, não tenho nenhum receio quanto a isso, mas a questão são as mudanças, 0 quanto essas mudanças vão impactar no core, e na essência do que o Instituto era e o que ele vai ser." (Entrevistada 4)

As reações iniciais do Entrevistado 5, estão intimamente ligados à sua participação nos processos de mudança. No primeiro caso que ele viveu era de expansão da empresa estatal, ele diz que já era esperado que a mudança acontecesse e, para ele, não foi um processo muito traumático, pois o processo era de forma evolutiva, não havia tanta urgência ou pressões para o alcance das metas. Ele explica que as urgências eram muito mais ligadas aos surgimentos das oportunidades, associadas às prioridades do projeto.

Já no segundo caso, de enxugamento da empresa, ele recebeu com surpresa a notícia que faria parte de um grupo de auxílio na implantação da 
mudança e que, desta vez, o processo é mais traumático, com muita expectativa, devido ao alto grau de incerteza e de instabilidade.

No processo de criação da nova área que era orientada por funcionalidades que aconteceu na empresa da Entrevistada 6, o seu sentimento foi bastante positivo, e alguma parte disso pode ser atribuído ao fato de ela se identificar mais com um modelo funcional do que com um voltado para segmentos de indústria:

"Eu fiquei muito feliz porque eu sempre fui uma das pessoas que sempre discutiu e levantou a hipótese da criação dessa área, quando ela ainda não existia." (Entrevistada 6)

Depois de 15 anos, quando a empresa decidiu retornar a um modelo semelhante ao antigo, ela diz que houve um sentimento de perda:

"E depois quando a empresa fez uma grande mudança de retorno para um modelo similar ao que ele era lá atrás, eu particularmente, não me senti bem, porque a sensação era de que a gente ia perder tudo aquilo que a gente tinha construído [...] O processo claramente traria outros ganhos em termos de resultado para a empresa como um todo, mas para quem participou e construiu aquilo tudo, deu esse sentimento de perda, de que algo que a gente construiu com muito custo, ia ser perdido e dissipado nas outras áreas." (Entrevistada 6)

Segundo ela, a área era pequena e dependia do desenvolvimento da área equivalente na sede no exterior, então, sempre que havia uma troca de liderança havia uma insegurança quanto ao futuro:

\footnotetext{
"Enquanto havia mudanças de liderança lá fora ou de forma de funcionamento lá fora, a gente sentia um desconforto e uma insegurança, será que vai funcionar? Será que essa pessoa vai continuar contribuindo? Será que todo aquele trabalho que a gente fez vai ser reconhecido? Será que vai continuar de pé? Será que vão mudar tudo?" (Entrevistada 6)
}

Ao longo do tempo, os sentimentos se confirmavam e outras vezes não. Em relação a primeira mudança, os sentimentos positivos se confirmaram, já na segunda situação ela diz que parte dos sentimentos de perda se confirmaram, mas, ainda assim, ela pode identificar alguns ganhos:

"Acho que como mudança ela não está madura ainda, conforme as outras, então pode ser que no futuro as coisas mudem, e 
evoluam, mas eu acho que parte deste sentimento se confirmou, porque houve de fato perda de conhecimento. Mas eu acho também, que tiveram outros ganhos dentro das industrias e oportunidades de desenvolvimento, de formação, de relacionamento, de carreira, então eu acho que foi meio a meio." (Entrevistada 6)

Neste caso, pode ser visto um exemplo do que foi dito por Palmer, Dunford e Akin (2009) sobre algumas razões de os indivíduos resistirem à mudança: os efeitos negativos percebidos em seus interesses. As pessoas dão mais suporte à mudança onde elas identificam algum ganho para si, contudo quando a mudança é vista como uma ameaça a seus interesses, a tendência é que resistam à mesma. A Entrevistada 6 teve mais desconforto quando a mudança não estava tão alinhada com seus interesses, o que não quer dizer que ela tenha adotado algum comportamento resistente, mas houve um desconforto maior.

Para a entrevistada 7, a percepção inicial era que com as mudanças no departamento de marketing ela teria muito mais trabalho para fazer e seria mais cobrada pelo seu desempenho:

“Bom, no começo, a gente falava: 'Lá vem mais trabalho' e foi exatamente que aconteceu. Então a gente já sabia.... Cria-se uma resistência, obviamente, porque você está absorvendo muito mais trabalho do que antes e vai ter que performar muito melhor. Então assim, começa a se criar um nível de exigência muito alto e você não tem nem tempo de respirar." (Entrevistada 7)

Para ela, não houve mudança dos sentimentos ao longo do tempo, o que houve para ela foi uma adaptação à nova realidade:

"Eu acho que ao longo do processo você só vai ficando mais confortável com aquilo de novo que te mandaram fazer [...]. Mas continuava sendo muito trabalho, a gente continuava sabendo que era muito trabalho, mas vai ficando mais confortável naquilo que fazia e você faz um pouco mais rápido." (Entrevistada 7)

Segundo Kotter (1997), as mudanças sempre geram algum custo para o indivíduo, que estará disposto a pagar, desde que consiga encontrar algum ganho associado. Este ganho não foi identificado pela Entrevistada 7 que via a cada nova mudança, uma nova carga de trabalho. 
Em contraponto a isso, Kets de Vries e Balazs (1999), dizem que muitos estudos têm considerado as pessoas como seres estritamente racionais que mudam seus comportamentos de acordo com as informações que recebem e agem de acordo com seus interesses próprios e as emoções, por sua vez, são tidas como irracionais, logo, não devem ser levadas em conta no mundo organizacional. Esses autores também acreditam na existência de um mundo interior repleto de desejos, anseios e fantasias, que deve ser atendido.

A Entrevistada 7 em algumas falas comenta que na empresa onde trabalha e passou por esse processo era muito difícil que os funcionários em geral recebessem elogios por seu trabalho, revelando uma necessidade interna não atendida.

O Entrevistado 8 diz que recebeu com tranquilidade a notícia de que haveria uma reestruturação em sua empresa, perguntado a que ele atribui ter tido esta reação num momento que ele considera como uma das mudanças mais drásticas que passou, responde:

"Muito ao conhecimento. Ter conhecimento da verdade [...]. Se pensar como indivíduo, eu acho que é fundamental você passar as turbulências da vida, que toda vida tem. Quando você tem um autoconhecimento, você passa esses momentos melhor, você sofre, você chora, tem perdas, essas perdas te machucam, deixam feridas, mas o teu autoconhecimento, te faz passar com mais leveza. Então, o conhecimento que eu tinha de administração, conhecimento que eu tinha da empresa, a visão que eu entendo que as empresas precisam ser competitivas... então, eu entendia que aquilo deveria ser feito... Que pena que eu que tava na linha de fogo!" (Entrevistado 8)

Ao analisar esta fala, observa-se, como no caso da Entrevistada 3, características de pessoas e organizações resilientes segundo Coutu (2002, apud Barlach, Limongi-França e Malvezzi, 2008) como, a firme aceitação da realidade e a crença profunda, apoiada por valores fortemente sustentados, de que a vida é significativa.

Isso, porém, não significa dizer que ele não teve sentimentos ou reações negativas. Quando houve o desligamento de vários funcionários de seu convívio ele sentiu muito essa perda e ficou muito triste, porém o entendimento da 
necessidade que o momento pedia, foi um dos fatores que o fez superar esses sentimentos. 


\section{Conclusões}

A forma como a mudança é conduzida pelos gestores impacta de maneira significativa a percepção, as reações e os sentimentos dos indivíduos que sofrem o processo de mudança.

Neste estudo foi analisado como a estruturação, a comunicação, o incentivo à participação e ao envolvimento, e a abertura que tiveram com as lideranças impactou de forma positiva ou negativa as percepções, reações e sentimentos dos colaboradores.

No quesito estrutura percebeu-se que quanto mais bem estruturada a mudança, quanto mais claros são seus objetivos e metas e a forma como eles serão atingidos, melhor é a reação dos indivíduos frente ao processo. Isso pode ser explicado pela garantia dada ao indivíduo de certa previsibilidade do que irá acontecer e isso, por sua vez, contribui para a redução das inseguranças e tende a aumentar o grau de controle que o indivíduo possui sobre a situação. Como diz Conner (1995), quando a necessidade de controle é atendida, reduzse o desconforto da insegurança.

A comunicação da visão da mudança deve ser clara, de forma a gerar um bom entendimento do processo, e está intimamente ligada à criação da visão de longo prazo da mudança, o que por sua vez, está relacionado ao seu planejamento e à estruturação. Não havendo este planejamento, fica difícil haver uma comunicação clara de onde pretende-se chegar. Outro fator importante na comunicação da visão da mudança é que a liderança deve comunicá-la não somente com palavras, porém com ações que são mais impactantes.

Outro ponto de atenção que surge em alguns casos é o fato dos rumores e da chamada "rádio corredor", ou seja, dos canais informais de comunicação que acontecem dentro da empresa, algo que é pouco falado pelos autores aqui estudados, mas que são de grande representatividade nos processos de mudança organizacional.

Quanto à participação e o envolvimento dos funcionários, os autores Kotter e Schlesinger (1979, apud Palmer, Dunford e Akin, 2008) defendem que quando há oportunidade para que os indivíduos participem e contribuam para o novo cenário é mais difícil que eles resistam às transformações, confirmando a teoria 
do desenvolvimento organizacional. Neste estudo, de acordo com os entrevistados, tal teoria foi confirmada, uma vez que aqueles que não se sentiram envolvidos no planejamento foram mais impactados negativamente, enquanto os colaboradores que contribuíram direta ou indiretamente com o planejamento se sentiram menos impactados pela mudança.

Os autores aqui estudados dizem que os líderes inteligentes estimulam o diálogo sobre percepções e sentimentos negativos durante o processo de mudança, pois o pior tipo de resistência a ser gerenciada é o tipo implícita. Nos casos estudados, somente três tiveram essa abertura com as lideranças e atestaram que isso foi um dos pontos essenciais para entenderem e transporem o processo.

No relato dos participantes as reações e percepções negativas não geraram comportamentos que impedissem a concretização do processo de mudança. Porém as reações negativas se bem administradas pela liderança poderiam ter sido minimizadas. Vale ressaltar que os principais sentimentos negativos causados foram: frustração, angústia, ansiedade, insegurança, pressão por mais produção nas mesmas condições.

Além dessas, outras questões de implementação da mudança também apareceram de maneira pontual, como por exemplo: a falta de uma liderança forte que demostrasse acreditar no processo, a falta de uma coalização administrativa, a divergência entre dircurso e prática e a necessidade da existência de uma área que ouvisse o indivíduo e pudesse fazer algo a respeito de suas percepções, principalmente nos casos onde não havia abertura com a liderança. Sobre tais, não houve maiores aprofundamentos, mas valem novos estudos, por exemplo sobre a importância da coalização administrativa e de como os objetivos individuais podem afetar na condução do processo.

Diante disso, concluímos que conforme apontado pelos autores aqui estudados, a mudança é sempre um processo difícil de ser conduzido e vivido, mas há práticas de gestão que podem contribuir para a redução das incertas do processo e inseguranças naturais dos indivíduos impactados, como: a estruturação, a comunicação, o incentivo à participação e ao envolvimento dos colaboradores e a abertura destes com suas lideranças. 


\section{Referências Bibliográficas}

BARLACH, Lisete; LIMONGI-FRANÇA, Ana Cristina; MALVAZZI, Sigmar. O conceito de Resiliência Aplicado ao Trabalho nas Organizações, Revista Internacional de Psicologia, v. 42, n.1, p 101-112, 2008.

CHIAVENATO, Idalberto. Introdução à Teoria Geral da Administração: Uma Visão Abrangente da Moderna Administração das Organizações. Rio de Janeiro: Elsevier, 2004.

CONNER, Daryl R. Gerenciando na Velocidade da Mudança. Rio de Janeiro: Infobook, 1995.

FORD, J.D.; FORD, L.W. The role of conversations in producing intentional change in organizations, The Academy of Management Review, v. 20, p. 54170, 1995.

GIL, Antonio Carlos. Como Elaborar Projetos de Pesquisa. São Paulo: Atlas S.A., 2002.

KOTTER, John P. Liderando Mudança. Rio de Janeiro: Campus, 1997.

LEWIN, Kurt. Frontiers in Group Dynamics: Concept, Method, and Rality in Social Sience. Human Relations, v. 1, n.1, p. 5 - 41, 1947.

PALMER, Ian; DUNFORD, Richard. Conflicting Uses of Metaphors: Reconceptualizing Their Use in the Field of Organizational Change. Academy of Management Review, v. 21, n. 3, p. 691-717, 1996.

PALMER, lan; DUNFORD, Richard; AKIN, Gib. Managing Organizational Change: A Multiple Perspectives Approach. Boston: McGraw-Hill Irwin, 2009. 
ROBBINS, Stephen P. Comportamento Organizacional. São Paulo: Pearson, 2004.

SILVA, J.R.G. Comunicação e mudança em organizações brasileiras: desvendando um quadro de referência sob a ótica do sujeito e da reconstrução de identidades. 2001. 490 p. Tese de Doutorado em Administração de Empresas - Instituto de Administração e Gestão, Pontifícia Universidade Católica do Rio de Janeiro, Rio de Janeiro.

SILVA, J.R.G; VERGARA, S. C. Sentimentos, Subjetividade e Supostas Resistências à Mudança Organizacional. Revista de Administração de Empresas-RAE, v. 43, n. 3, p. 10-21, 2003.

TOFFER, Alvin. Choque do Futuro. Lisboa: Livros do Brasil, 1970. 


\section{Apêndice}

\section{Roteiro de Pesquisa}

1. Qual a sua formação?

2. Quanto tempo você tem de trabalho?

3. Quais funções já exerceu?

4. Qual mudança organizacional que você passou que mais te impactou? Em qual empresa?

5. Por que foi a que mais te impactou?

6. Do que se tratou a mudança?

7. Quanto tempo durou? (Se já teve um fim)

8. Como você ficou sabendo que a mudança iria acontecer?

9. Como a mudança aconteceu? Houve etapas?

10. Quais os fatos marcantes da mudança?

11. Como foi o nível de urgência?

12. Qual foi a sua reação ou sentimento inicial ao saber que a mudança iria acontecer?

13. Essa reação ou sentimento mudou ao longo do processo?

14. Quem eram as pessoas responsáveis por fazer a mudança acontecer?

15. Você pôde falar de seus sentimentos, percepções ou reações com alguém que era responsável pela implementação da mudança?

16. Você tinha alguma responsabilidade ou participação no processo de mudança?

a. Se sim, qual? Por que você acha que Ihe foi atribuída?

b. Se não, por que você acha que não the foi atribuída nenhuma participação/responsabilidade? 